\title{
Prehistoric paleoecology of Easter Island
}

\author{
Valentí Rull \\ Botanic Institute of Barcelona (CSIC), Pg. del Migdia s/n, 08038 Barcelona, Spain. Email: vrull@csic.es
}

\begin{abstract}
This chapter reviews the paleoecological research developed to date on Easter Island (Rapa Nui) and places the main findings within the appropriate cultural chronological context, working towards a more holistic framework of Easter Island's prehistory. Emphasis is placed on the climatic and ecological changes that have occurred during the last millennium, their potential causes and their possible influence on sociocultural trends and events. Three main phases in the history of Easter Island paleoecological research are recognized: the pioneer phase (1977-1992), the intermediate phase (19932004) and the revival phase (2005-present). During the pioneer and intermediate phases, the paradigm of self-induced socioecological collapse dominated the thinking about this site. However, new evidence obtained during the revival phase highlighted the potential significance of climatic changes and climatehuman synergistic effects for prehistoric ecological and cultural development. The contribution of paleoecology to developing a better understanding of Easter Island's prehistory is discussed with a focus on four main points: (i) the discovery and settlement of the island, (ii) the occurrence of climatic changes and their natural and anthropogenic drivers, (iii) spatiotemporal deforestation patterns and (iv) the potential relationship between climatic, ecological and cultural shifts. Insights regarding possible future research directions are provided, and a theoretical framework, referred to as EHLFS (Environmental-Human-Landscape Feedbacks and Synergies), is proposed to develop a more holistic view of Easter Island's prehistory.
\end{abstract}

\section{Keywords}

Rapa Nui, paleoecology, paleoclimatology, early settlement, deforestation patterns, climatic changes, cultural shifts

\section{Introduction}

Paleoecological knowledge has largely been neglected in the study of Easter Island's prehistory, defined as the time interval between Polynesian settlement (800-1200 CE) and European contact (1722 CE). The initial works of Flenley and coworkers, carried out approximately four decades ago (Flenley \& King, 1984; Flenley et al., 1991), were taken by many as the final word in Easter island paleoecology. These pioneering works demonstrated that the island was deforested during the last millennium and that the original palm-dominated forests never recovered. Following an earlier, hitherto unverified, hypothesis of Mulloy (1974), forest clearing was linked by Flenley et al. (1991) to the human overexploitation of natural resources, which would have caused starvation, social conflicts and wars, leading to the cultural collapse of the prehistoric Polynesian society living on the island (thereafter, the ancient Rapanui society). Bahn \& Flenley (1992) considered the socioecological demise of Easter Island as a microcosmic model for the whole planet and warned about current global exploitation practices based on the premise of unlimited growth and human selfishness. The idea of a self-induced cultural collapse, also known as the ecocide theory (Diamond, 2005), was considered the paradigm of Easter Island's prehistory and dominated the scene for decades, not only in the scientific arena but also in the press 
and other popular media. However, a number of issues, such as the deforestation chronology and its spatial patterns across the island as well as the potential influence of climate changes and synergistic climate-human effects on ecological change, remain unclear and require further paleoecological research (Rull, 2016a; Rull et al., 2013, 2016). In addition, some archaeological evidence suggests that the ancient Rapanui did not experience a prehistoric population demise but remained a healthy society until European contact (Hunt, 2006, 2007; Mulrooney, 2013; Mieth \& Bork, 2015, 2017; Stevenson et al., 2015). As a result, the ecocide paradigm was called into question, and the search for a more holistic view that includes the possible influence of climatic changes and/or synergistic climate-human effects was recommended (Rull, 2018).

One constant in research on Easter Island, including the pioneering paleoecological works of Flenley and coworkers, has been the idea that the climate remained constant or that small climatic variations were not influential in prehistoric ecological and cultural developments (Flenley et al., 1991). For example, Bahn \& Flenley (1992) dismissed a potential influence of climate on deforestation, claiming that it "seems odd that the forest should survive for at least 37,000 years, including the major climatic fluctuations of the last ice age and the postglacial climatic peak, only to succumb to drought after people arrived on the island". These authors therefore concluded that only humans were responsible for forest clearing. The idea of climatic constancy was also extended to other research disciplines (e.g., archaeology, anthropology, ethnography), which adopted it as one more paradigm, a paradigm still in force today.

Shortly after the pioneering paleoecological works of Flenley and his colleagues, some researchers suggested the possibility that climatic changes, especially droughts, were involved in the ecological and cultural collapse on the island (McCall, 1993; Haberle \& Chepstow-Lusty, 2000; Orliac \& Orliac, 1998; Hunter-Anderson, 1998; Nunn, 2000; Nunn \& Britton, 2001). However, most of these proposals were based on climate change records from distant locations (e.g., Australasia, New Zealand, South America) or regional climatic patterns, and in situ evidence of climate shifts on Easter Island remained absent. According to most of these authors, interannual variability in regional climatic mechanisms such as the El Niño-Southern Oscilation (ENSO) could have affected Easter Island's climate during the prehistoric period. However, the possible influence of the ENSO on the island's climatic variability was not universally accepted and remained controversial (Maclntyre, 2001; Genz \& Hunt, 2003; Stenseth \& Voje, 2009; Caviedes \& Waylen, 2011).

In the following decades, paleoecological studies intensified, and clear evidence of prehistoric climatic changes on Easter Island was obtained (Mann et al., 2008; Sáez et al., 2009; Cañellas-Boltà et al., 2013; Rull et al., 2015). It was also demonstrated that deforestation was not homogeneous over time and space but, rather, occurred at different times and at different rates across the island (Rull, 2020a). In addition, although paleoecology has not provided direct evidence regarding a number of cultural matters on Easter Island, it has furnished empirical information that can aid in understanding processes such as initial discovery (Rull, 2019) or the potential role of climate changes and synergistic climatehuman effects on significant prehistoric cultural shifts (Rull, 2016a, 2020b).

This paper reviews the paleoecological study of Easter Island's prehistory, with emphasis on the research developed during the last two decades, which has been particularly overlooked. The paper begins with a brief section about the cultural chronology of Easter Island, which is needed to place paleoecological discussions in an appropriate temporal context. Then, the paleoecological sites that have been studied to date on the island are briefly described, with emphasis on sedimentary freshwater bodies and the cores retrieved from them. This is followed by a succinct historical account of paleoecological studies, with emphasis on the last decade, which has witnessed a significant resurgence of paleoecological work. The most relevant paleoecological findings are summarized and discussed with regard to four main thematic issues: settlement, climatic change, deforestation and cultural change. 
Finally, some remarks related to possible future research and the need for interdisciplinary studies aimed at achieving a holistic view of Easter Island's prehistory are provided.

\section{Prehistoric chronology}

Traditionally, the prehistory of the island has been subdivided into three main periods, but agreement on the names of these periods and the boundary dates between them has yet to be reached, which hinders the development of a generally accepted chronology (Lipo \& Hunt, 2016). The different chronological schemes are presented and discussed in more detail in Rull (2020a), here only the main features and disagreement points are summarized.

The arrival of the Polynesian settlers who developed the ancient Rapanui society on the island has been dated to between 800 CE and 1200 CE by different authors (Steadman et al, 1994; Martinsson-Wallin \& Crockford, 2002; Flenley \& Bahn, 2003; Hunt \& Lipo, 2006; Vargas et al., 2006; Kirch, 2010; Wilmshurst et al., 2011). There is still no consensus and some authors do not recognize a presence before $1200 \mathrm{CE}$, shich complicates a phased approach.

The settlement phase, also known as the Early Period or Ahu Moroki, would have extended until approximately $1200 \mathrm{CE}$ and was likely a phase of adaptation of the Polynesian colonizers to their new environments, linked to cultural activities with a low ecological impact on the landscape (Mieth \& Bork, 2010). Heyerdahl (1952) contended that the first settlers were not Polynesians but Amerindians (or Native Americans), who arrived on the island by 400 CE but were further eradicated by the Polynesian settlers. However, this author did not provide convincing evidence, and his proposal was deeply questioned by Flenley \& Bahn (2003), who defended the notion that Easter Island was colonized only once, from East Polynesia. Recent genomic studies have suggested that the Amerindian influence on ancient Rapanui society can be dated back to pre-Columbian times (1280-1495 CE), although it is not clear whether Native Americans arrived on Easter Island by their own or were brought there by Polynesians after traveling to America (Thorsby, 2007, 2016). Repeated pre-Columbian voyages of Polynesian navigators to America between $700 \mathrm{CE}$ and $1350 \mathrm{CE}$ have been supported by consistent evidence from a wide range of disciplines (Jones et al., 2011; Rouiller et al., 2013).

The second period - Middle Period, Ahu Moai or Expansion Phase, also known as Golden Age (Boersema, 2015) - would have been the time of a flourishing ancient Rapanui society, characterized by a significant population increase, the development of the moai sculpture industry and cult, and the general deforestation of the island. During this phase, the cultural center of Rapanui society was the quarry where the megalithic sculptures, tought to represent chiefs (ariki, known as moai were carved (Rano Raraku) (Fig. 1). The maximum authority of the island, the Ariki Mau, was always the chief of the Miru clan, considered to be a direct descendant of the first Polynesian settlers. This phase would have ended between 1500 CE and 1680 CE (Smith, 1961; Kirch, 1984; Flenley \& Bahn, 2003; Vargas et al., 2006; Nunn, 2007; Boersema, 2015).

The third phase (Late Period, Huri Moai or Decadent Phase) is thought to have been characterized by the end of the former Rapanui splendor, as manifested in a demographic decline, a deforested island and a general exhaustion of natural resources, leading to starvation, social conflicts and wars. Social conflicts among clans would have led to the toppling and breakage of the moai and the destruction of the stone altars (ahu) where they were erected and emplaced for worship. This would have led to a profound social, religious and political shift from the ancestor worship (also known as Moai Cult) to the Birdman Cult, in which the Ariki Mau was no longer a permanent authority selected according to dynastic rules (Robinson \& Stevenson, 2017). Under the new cult, the maximum authority of the island, the Birdman (Tangata Manu), was reselected each year after an athletic competition aimed at obtaining the first egg of the migratory sooty tern (Onychoprion fuscatus), considered a symbol of fertility, which nested in the adjacent Motu Nui Islet each Austral spring. The Birdman cult was centered on the 
ceremonial village of Orongo, situated on the SW crest of Rano Kao (Fig. 1), which replaced Rano Raraku as the cultural center of Rapanui society. The end of the third period and of the island's prehistory was marked by the arrival of the first European explorers, in 1722 CE, but the ancient Rapanui culture continued, as reflected in the archaeological record.

This classical three-stage chronology has largely been influenced by the ecocide paradigm, as manifested in the purported occurrence of a profound social crisis and a demographic crash due to the depletion of natural resources, which characterized the transition between the second and third periods. The situation would have been different under a scenario of resilience of the ancient Rapanui society to island deforestation. The widespread use of protected stone structures for cultivation (manavai) and the use of novel methods to minimize evaporation and temperature fluctuations (lithic mulching) would have allowed the continuity of the Rapanui population with no significant declines (Stevenson et al., 1999; Wozniak, 1999, 2001, 2017; Mulrooney, 2013; Mieth \& Bork, 2015, 2017; Stevenson et al., 2015; Jarman et al., 2017). Regarding the shift from the ancestor worship to the Birdman cult, some authors have suggested that this was a postcontact characteristic (Robinson \& Stevenson, 2017). In addition, some historians suggest records that moai toppling might have occurred after European contact, as a result of the exacerbation of rivalry among the Rapanui clans competing for the position of Birdman (Fischer, 2005). Historical records also show that the true cultural collapse of Rapanui society and culture occurred long after initial European contact and actually took the form of a genocide (Peiser, 2005; Hunt, 2006, 2007). Indeed, slavery practices and the introduction of epidemic diseases hitherto unknown by the Rapanui (syphilis, smallpox, tuberculosis) led to a population collapse that reduced the population of 3000-4000 people reported by the first European visitors to barely 110 individuals in 1877 (Pinart, 1878). In addition, by 1868, the whole population of the island approximately 800 people by that time - had been Christianized and therefore acculturated.

In summary, a robust chronology of prehistoric human developments on Easter Island remains to be defined. According to Lipo \& Hunt (2016), the most precise information available concerns the timing of Polynesian settlement - which these authors place at 1220-1260 CE (Hunt \& Lipo, 2006) - and the arrival of Europeans, in 1722. The interval between these two dates can only be defined as "the past", with little more precision than that (Lipo \& Hunt, 2016). Based on the above discussion, a tentative chronology might be represented by a continuum defined by the following processes, with loose and sometimes overlapping boundaries: deforestation (800-1200 CE to 1450-1650 CE), moai cult or ancestral worship (1200 CE to 1600-1650 CE), Birdman Cult (1600-1850 CE), moai toppling (1770s-1830s CE) and the genocide (1860s-1870s CE).

\section{Paleoecological archives}

Easter Island includes only three freshwater bodies with sediments suitable for paleoecological research: Rano Aroi, Rano Kao and Rano Raraku (Fig. 1). Other archives that may contain paleoecological evidence include soils and archaeological sites, which are widespread across the island. In marine environments, corals are potential paleoecological archives that have been poorly exploited to date and deserve further consideration.

\subsection{Sedimentary basins}

Rano Aroi is a swamp/mire of $150 \mathrm{~m}$ in diameter located at a $430 \mathrm{~m}$ elevation near the Terevaka summit (Fig. 1). Its water level is controlled by groundwater inputs subject to the influence of seasonal variations in precipitation and human extraction through the construction of an artificial outlet in the 1960s (Herrera and Custodio, 2008). The aquatic vegetation is dominated by Scirpus californicus, Polygonum acuminatum and ferns of the genera Asplenium, Vittaria and Cyclosorus, whereas the surrounding area is covered by grasslands and a small Eucalyptus forest planted during the 1960s (Zizka, 1991). The mire 
infilling is predominantly peat and is at least $16 \mathrm{~m}$ deep in the center, which may correspond to an age of approximately 70,000 yr BP (extrapolated age) (Margalef et al., 2013, 2014).

Rano Kao contains the largest lake of the island, with a diameter of $1250 \mathrm{~m}$, located at a $110 \mathrm{~m}$ elevation. This lake is very peculiar, as its surface is a mosaic of water and aquatic vegetation taking the form of floating mats up to 3-4 m deep overlying the water column, which is approximately $10 \mathrm{~m}$ deep near the center. This configuration determines the existence of two different paleoecological archives: the superficial floating peaty mat and the more clastic bottom lake sediments accumulated below the water column. The floating mats are dominated by the characteristic semiaquatic species of the island, Scirpus californicus and Polygonum acuminatum, together with another sedge, Pycreus polystachios (Zizka, 1991). The oldest ages recorded so far in the floating mat correspond to the last millennium (Gossen, 2007; Horrocks et al., 2013). A significant number of archaeological sites have been found within and around the Kao crater, including the ancient village of Orongo, formed by stone houses, which is one of the more important and well preserved archaeological complexes of the island (Robinson \& Stevenson, 2017). The maximum depth of the lake sediments recorded thus far is approximately $21 \mathrm{~m}$ (but it is supposed to be deeper, as hard rock has not been reached), and the maximum age is 34,000 cal y BP (Gossen, 2007, 2011; Horrocks et al., 2013).

Rano Raraku contains a small and shallow lake of $300 \mathrm{~m}$ in diameter and 2-3 m in depth, located at an 80 $m$ elevation. Hydrologically, the lake is closed, with no surface outlet, and is used by humans as a freshwater source for consumption. The main water inputs are rainfall and catchment runoff (Herrera \& Custodio, 2008). The water level is influenced by periodic water extraction, and the maximum depth recorded in modern times is approximately $3 \mathrm{~m}$ (Sáez et al., 2009); however, in some years, the lake may be totally dry. The aquatic vegetation is dominated by Scirpus californicus, which forms a more or less continuous floating belt (partly rooted in lake sediments) along the east margin of the lake, where the input of terrigenous materials from the catchment is greater and more continuous. Rano Raraku is one of the more emblematic sites of the island, as it was the quarry where the moai were carved. Many of these stone statues, some of which are unfinished, remain on the east side of the crater, where most of the moai were formed. The sedimentary infilling is at least $14 \mathrm{~m}$ deep in the center of the lake, which corresponds to an age of 34,000 cal yr BP (Sáez et al., 2009).

Cores from the Aroi, Kao and Raraku sediments have been retrieved from different parts of these craters using a variety of coring equipment and extrusion techniques. Figure 1 shows the location of all cores obtained to date where the results have been. Table 1 displays the main features of each core and the main paleoclimatic and paleoecological proxies studied. The EIRA (Easter Island Radiocarbon Ages) database, which includes all radiocarbon dates obtained in these sediments (Rull, 2016b), is publicly available at the NOAA Paleo Data website (www.ncdc.noaa.gov/paleo-search/study/19805).

\subsection{Other archives}

In addition to lake and swamp sediments, other paleoecological archives have been investigated on Easter Island, although less intensively. A coral paleoclimatic record covering only the second half of the $20^{\text {th }}$ century is available, although the authors of the study providing these data estimate that Easter Island's corals have the potential to span at least 250 years and possibly 400 years (Mucciarone \& Dunbar, 2003). The study of soil profiles and selected materials from some archaeological sites has also provided paleoecological information, mainly on the nature of the ancient forests and deforestation timing. In several of these archives, Mann et al. (2003) and Mieth \& Bork (2005, 2010, 2015, 2017) found evidence of slash and burn activity, agroforestry, forest clearing and regeneration, soil erosion and other ecological processes. In other dryland soils and archaeological sites, Horrocks \& Wozniak (2008) and Horrocks et al. (2016) found evidence of forest clearing and the cultivation of Polynesian crops. At some archaeological sites, Orliac (2000) and Orliac \& Orliac (1998) identified woody plant taxa from charcoal fragments. The usual proxies utilized in the study of soils and archaeological sites have been soil 
stratigraphy, with an emphasis on carbon layers, charred wood/endocarp and palm root casts, charred wood, pollen, phytoliths, and starch remains.

\section{Historical development of paleoecological studies}

Paleoecological studies on Easter Island have their origin in some undated cores retrieved in the mid$20^{\text {th }}$ century by Thor Heyerdahl, which were analyzed for pollen by Olof Selling, but the results remained unpublished. The only information available is a personal communication from Selling to Heyerdahl suggesting that the island was probably forested at some time in the past (Heyerdahl \& Ferdon, 1961). These forests must have disappeared before European contact, as the first Europeans to arrive found a treeless island (Fischer, 2005). The idea of a forested island had previously been proposed, albeit without empirical evidence, in the late $18^{\text {th }}$ century by La Pérouse (1797), who also speculated that the ancient Rapanui would have cut down all the trees, making the island inhabitable. Mulloy $(1974,1979)$ related the initial palynological evidence to his own findings identifying palm root molds associated with carbonized wood in ancient soils, which were interpreted as remnants of former palm forests. In a paper written in 1976 but not published until two decades later, Mulloy (1997) emphasized the need for repeating and extending the paleobotanical studies initiated by Selling to test the hypothesis of a formerly forested island. From this point onwards, the sediments of the suitable sites (Rano Aroi, Rano Kao and Rano Raraku) began to be systematically cored and dated. However, the historical development of these studies was a discontinuous process due to the occurrence of a hiatus of approximately ten years (1993-2004) characterized by a significant reduction in paleoecological research activity, which separated the more active pioneer (1977-1992) and revival (2005-present) phases (Fig. 2). A detailed account of the analyses performed, the interpretation of the obtained results and the conclusions that were drawn is available from Rull (2020a); here, only a summary will be provided.

\subsection{The pioneer phase}

The first systematic paleoecological studies based on dated sediments were performed by a single research team led by the palynologist John Flenley. All the work developed during this phase was based on the analysis of pollen and other proxies from cores obtained between 1977 and 1983 in Rano Aroi, Rano Kao and Rano Raraku and was published between 1979 and 1992 (Flenley, 1979; Dransfield et al., 1984; Flenley \& King, 1984; Flenley et al., 1991; Bahn \& Flenley, 1992). The synthesis of all these works constituted the first general paleoenvironmental and paleoecological reconstruction for Easter Island, which was summarized by Flenley et al. (1991) in a graphical synthesis (Fig. 3). The same authors synthesized their findings into five main conclusions (Flenley et al., 1991):

1. Easter Island was formerly forested, and the main trees included an unknown palm, Sophora toromiro and Triumfetta semitriloba.

2. The uppermost altitudinal limit of this forest probably consisted of a shrub belt dominated by Coprosma and an unknown Compositae-Tubuliflorae species. This upper boundary was located near the elevation of Rano Aroi $(430 \mathrm{~m})$ but oscillated in response to climatic changes.

3. The climate of Easter Island fluctuated between 38,000 and $26,000{ }^{14} \mathrm{C}$ yr BP. Between 26,000 and $12,000{ }^{14} \mathrm{C}$ yr BP, the climate was probably cooler and drier than in the present. The magnitude of this cooling would have been $2{ }^{\circ} \mathrm{C}$ or less compared to present average temperatures. A precipitation (or moisture balance) increase occurred beginning at $10,000{ }^{14} \mathrm{C}$ $\mathrm{yr}$ BP. The uppermost forest limit increased in elevation at this time, which suggested a coeval rise in temperature.

4. Anthropogenic forest clearance took place between 1200 and $800{ }^{14} \mathrm{C} \mathrm{yr} \mathrm{BP} \mathrm{(ca.} 900$ and 1260 $\mathrm{CE})$, and the total demise of the forest occurred at $500{ }^{14} \mathrm{C}$ yr BP (ca. $\left.1450 \mathrm{CE}\right)$, which is compatible with the hypothesis that the decline of the megalithic culture was associated with deforestation. 
5. The hypothesis that Easter Island is poor in woody species due to its isolation is not supported by these results, which are more compatible with the view that human activities were responsible for the present-day floristic depauperation.

The pioneering paleoecological work developed by Flenley and his coworkers on Easter Island seemed to strongly support the ecocide hypothesis explicitly proposed some decades before by Mulloy (1974). Regarding a potential role for climatic change in this ecological and cultural demise on the island, Bahn and Flenley (1992) considered it implausible that forests that had survived major climatic fluctuations such as the last ice age and postglacial warming perished because of the occurrence of a drought just after island colonization by humans. For these authors such a coincidence was difficult to believe. A year later, Bahn \& Flenley (1992) published the first sociecological synthesis for the island, based on the chronology of the Rano Kao palynological record and the archaeological, ethnographical, anthropological and historical evidence available at that time. These authors suggested that in addition to its religious motivations, the moai sculpture industry was a strongly competitive activity among clans aimed at producing the largest and most spectacular monuments. The moai workers were dedicated exclusively to this task and should have been maintained by other sectors of society dedicated to food production. As moai activity increased, food producers had to support ever-increasing numbers of nonfood producers, which led to deforestation and vegetation depletion by burning and cutting, leaching and soil erosion, increasing evaporation and, ultimately, decreasing crop yields. This would have also caused the drying up of springs and streams. At the same time, the disappearance of large timber for canoe building eventually led to the abandonment of deep-sea fishing and prevented the islanders from navigating to other islands.

In agreement with Mulloy (1974), these authors considered the communal compulsion of the ancient Rapanui to produce giant statues and platforms "insane", to the point that basic subsistence activities such as farming and fishing were neglected. Bahn \& Flenley (1992) considered Easter Island to be a microcosm model for the whole planet, as both are isolated systems and have limited resources. Therefore, Easter Island may be viewed as a real experiment regarding the consequences of the overexploitation of natural resources, from which we can extract important lessons for the future of the Earth. However, Bahn \& Flenley (1992) identified some obstacles to achieving this goal. One is the selfishness inherent to human nature, which prioritizes our own short-term goals rather than general social interests, and the other is the current attachment to unlimited growth, which ignores the preservation of natural resources for future generations.

\subsection{The transitional phase}

After the consolidation of the collapse theory by pioneering studies, paleoecological research on Easter Island experienced a hiatus of approximately a decade, which is referred to as the transitional phase here. This phase was characterized by sporadic, nonsystematic coring and the publication of only a few papers, which did not introduce significant modifications to the collapse paradigm. During this phase, paleoecological chronology research took a step backward, as most coring campaigns produced chronologically inconsistent sequences with frequent sedimentary gaps and age inversions, which prevented the development of reliable age-depth models. This was the case for Rano Kao (Flenley, 1998), Rano Aroi (Peteet, 2003) and Rano Raraku (Dumont et al., 1998).

The occurrence of age inversions within radiocarbon dating depth sequences was attributed to the contamination of younger sediments with older carbon from different sources. After a detailed analysis of radiocarbon dates in a newly obtained sedimentary sequence from Rano Kao, Butler et al. (2004) concluded that it was not possible to draw conclusions about the ecological history of the island due to significant chronological inconsistencies. These authors recommended the development of additional coring activities and new chronologies after the careful selection of the materials to be dated. A new core with similar dating problems was obtained in Rano Raraku by Dumont et al. (1998). After the 
analysis of planktonic organisms from the most recent sediments, these authors suggested that Amerindians from the Inca Empire would have arrived on Easter Island by 1300-1450 CE and may have contributed to cultural collapse by halting the tradition of moai carving.

The most informative paleoecological reconstruction carried out during the transitional phase was performed by Mann et al. (2003), combining island-wide edaphic studies and a new sedimentary sequence from Rano Raraku. An island-wide analysis of buried primeval soils - i.e., those that supported former forests - revealed that general deforestation likely occurred between 1200 and $1650 \mathrm{CE}$, coinciding with the phase of megalithic statue construction (Fig. 4). This was supported by the study of a new core obtained in Rano Raraku, where evidence for major forest burning and soil erosion was recorded from 1070-1280 CE. Mann et al. (2003) noted that this occurred long after the initial human settlement of the island and suggested that the island might have been occupied, perhaps transiently, by Polynesian hunter-gatherers thriving on its rocky shores. Permanent settlement, dryland farming and population growth might have been initiated by $1200 \mathrm{CE}$, leading to the ecological transformation of the island.

Orliac (2000) and Orliac \& Orliac (1998) analyzed charred pieces of wood from some archaeological sites and identified a number of woody taxa from the $14^{\text {th }}$ to $17^{\text {th }}$ centuries. A number of these taxa are no longer present on the island, and it was speculated that they might have been components of the ancient forests, or trees/shrubs cultivated temporarily by the prehistoric Rapanui or drift wood used for fire. Cummings (1998) performed the first phytolith and starch analyses on Easter Island and realized that the preservation of these proxies at archaeological sites was good enough to provide information on deforestation and Rapanui cultivation practices.

\subsection{The revival phase}

The revival phase can be subdivided into two well-differentiated parts. The first part extended between 2005 and 2010 and was characterized by a significant increase in coring activities and the reanalysis of previously obtained cores. The second part (2012-present) was marked by the publication of the analyses performed on the cores obtained between 2005 and 2009.

\subsubsection{Coring intensification and reanalysis}

During the first part of the revival phase, a total of 20 cores were retrieved, almost half (9) of which were from Rano Raraku, while seven were from Rano Kao, and four were obtained in Rano Aroi (Table 1). Some preliminary results from these cores (Azizi \& Flenley, 2008; Gossen, 2007; Sáez et al., 2009) along with some reanalyses of older cores (Mann et al., 2008; Butler \& Flenley, 2010) were published during the same time interval. All of these papers were related to Rano Raraku and Rano Kao (Fig. 1). Using the Rano Raraku core of Mann et al. (2003), the same authors identified a sedimentary gap of more than 3000 years - 4090-4410 cal yr BP to $660-770$ cal yr BP (1180-1290 CE) - that was attributed to a climatic drought or a series of droughts, causing lake to dry up (Mann et al., 2008). This drought was attributed to a latitudinal shift in the subtropical storm track, which controls the intensity and frequency of cyclonic storms on Easter Island. This was the first local, independent evidence of prehistoric climate change on Easter Island. Pollen analysis of the same core documented abrupt forest clearing by $1200 \mathrm{CE}$, in accord with previous edaphic studies by the same authors (Mann et al., 2003) (Fig. 4). The deforestation of the Raraku catchment was not linked to the drought mentioned above, as the decline of palms and a coeval charcoal increase, interpreted as evidence of anthropogenic forest burning, occurred after the sedimentary gap.

The occurrence of an extensive depositional gap across Rano Raraku sediments was confirmed by a further systematic study based on a N-S transect of new cores retrieved in 2006 (Table 1), combined with those from older studies (Sáez et al., 2009). This hiatus extended between approximately 5888- 
4200 cal yr BP and 550-850 cal yr BP (1100-1450 CE) and was related to the mid-Holocene aridity crisis documented elsewhere in the circum-Pacific area. According to Sáez et al. (2009), this extended drought would have been caused by an insolation minimum, leading to the weakening of the summer monsoon, or in agreement with Mann et al. (2008), the southern shift of storm tracks forced by El Niño-like dominant conditions in the South Pacific.

In 2005, the first core with a chronologically coherent age-depth model, obtained using Scirpus californicus (totora) seeds as dating material, was retrieved in Rano Kao (Gossen, 2007, 2011). Preliminary sedimentological analyses of this core suggested a sudden increase in soil erosion, possibly linked to deforestation, by 650-720 CE. Further pollen analyses were carried out to confirm this fact, but to the knowledge of the author, this work remains unpublished. Butler \& Flenley (2010) resumed the analysis of their problematic Rano Kao core using totora seeds as dating material and obtained a more consistent age-depth model. Pollen analysis revealed the occurrence of two main deforestation events associated with conspicuous charcoal increases. The first event (50-100 CE) occurred long before the hitherto accepted Polynesian settlement of the island, and the origin of the fires involved was considered to be problematic. The second event (1350-1800 CE) was chronologically consistent with human deforestation by fire. For Butler \& Flenley (2010), the most interesting feature of this core was the possibility that human disturbance began approximately $100 \mathrm{CE}$ and continued thereafter, possibly varying in intensity but never ceasing. However, according to these authors, this interpretation would contradict most archaeological reconstructions, and more research is needed for a sound assessment.

Soil investigations have also provided relevant information on Easter Island's prehistory during the first part of the revival phase. Using the density and distribution of palm root casts in primeval soils across the island, Mieth \& Bork (2010) estimated that approximately 16 million palm trees had once grown on the island, covering approximately $70 \%$ of its surface. The same authors later extended their estimate to 20 million palms, covering $80 \%$ of the island (Mieth \& Bork, 2015, 2017). The radiocarbon dating of soil charcoal at different points on the island yielded dates of $1200 \mathrm{CE}$ and $1500 \mathrm{CE}$ for the beginning and the end, respectively, of intensive slash and burn practices across the island. The lack of evidence for extensive and intensive palm fruit eating by rats led these authors to conclude that the island-wide forest clearing was exclusively human caused. As in the case of Butler \& Flenley (2020), robust evidence of forest regeneration (i.e., the occurrence of two generations of root casts) after fire was found in soil profiles (Mieth \& Bork, 2010).

\subsubsection{Publication resurgence}

During the second part of the revival phase, the renewed coring efforts of the 2005-2009 period began to bear fruit in the form of papers reconstructing the main paleoecological trends of the last millennia, mainly through pollen analysis but also based on a variety of physico-chemical proxies that provided independent evidence for climatic and environmental change. This phase has been subdivided into two main categories according to the aims of the corresponding paleoecological studies. The first category encompasses studies based on biological analyses (pollen, phytoliths, starch, diatoms, arthropods) of cores from the three craters and an island-wide soil survey focused mainly on the reconstruction of prehistoric cropping activity. The second category includes multiproxy (physical, chemical and biological) studies on continuous, mostly gap-free, cores from the same waterbodies, aimed at reconstructing the spatiotemporal deforestation patterns and their potential climatic and/or anthropogenic drivers.

Horrocks et al. (2012b) studied several cores retrieved along the SW margin of Rano Kao, just below the ceremonial village of Orongo (Fig. 1), the center of the Birdman cult. The obtained results suggested terracing for gardening and dwelling within the crater. The radiocarbon dating of the four cores retrieved (albeit using totora fruit/seeds) again showed frequent age inversions, which prevented the development of a reliable chronology. The obtained results were consistent with a mixed-crop production system including common Polynesian cultigens such as paper mulberry (Broussonetia 
papyrifera), taro (Colocasia esculenta), yam (Dioscorea alata), sweet potato (Ipomoea batatas), bottle gourd (Lagenaria siceraria) and banana (Musa sp.). This study demonstrated that the SW margin of Lake Kao was an actively cultivated area during and after its deforestation, likely favored by the continuous availability of water and protection from the dominant winds. One of the obtained cores showed a chronologically consistent sequence between approximately 3500 and 1000 cal yr BP (1550 BCE and 950 $\mathrm{CE})$. Microfossil analysis of this interval revealed the occurrence of three events of forest clearing by burning and cultivation (notably banana) between 1730 and 930 BCE, 1110 and 800 BCE, and 660-770 CE (Fig. 5). The authors considered the third of these events to be chronologically consistent with Polynesian settlement, but the other two events occurred long before that time, and the authors discussed the possibility of contamination by older carbon from different sources.

In Rano Raraku, Horrocks et al. (2012a) found evidence of forest clearing and the appearance of cultivated plants such as taro and sweet potato by 1320-1440 CE. These authors concluded that the Raraku catchment and its surroundings were used not only as a moai quarry but also as an extensive multicropping site and suggested that the crater was intensively gardened and terraced, possibly during the peak of the moai-quarrying period. Horrocks et al. (2015) also obtained cores from Rano Aroi, and although the age-depth model was poorly constrained between approximately 12,000 and $1000 \mathrm{cal} \mathrm{yr}$ BP (950 CE), the results for last millennium were chronologically coherent and suitable for paleoecological study. Anthropogenic deforestation by burning occurred between approximately 1150$1300 \mathrm{CE}$ and 1520-1770 CE, and the first signs of human occupation and agricultural activity (banana, paper mulberry) were recorded between 1670 and $1740 \mathrm{CE}$, which was later than in the lower sites (Kao, Raraku). The absence of sweet potato is noteworthy. Another relevant finding was the consistent presence of Sisyrinchium, an invasive American weed, since at least 410-630 CE.

The study of prehistoric agricultural activities using microfossils was completed with an extensive survey of dryland soils across the island, carried out by Horrocks et al. (2016). Only one of the soil profiles studied was dated, but the general stratigraphic similarity suggested to the authors that all of the profiles corresponded to times after Polynesian settlement. Microfossil analyses similar to those developed in lake cores allowed the identification of the same cultivated plants recorded in lake terraces, showing no cultivation specialization between lake shores and dryland soils. The most widespread species were paper mulberry, taro and sweet potato.

The second category of paleoecological studies were focused on the multiproxy analysis of continuous and chronologically coherent (i.e., free from large sedimentary gaps and age inversions) records of the last millennia, which were able to provide independent paleoclimatic and paleoecological reconstructions, thus avoiding circularity. Three cores encompassing continuous records of this type were obtained in Rano Raraku, Rano Aroi and Rano Kao (Fig. 6).

In the Rano Raraku core, two smaller sedimentary gaps were detected, between approximately $500 \mathrm{CE}$ and $1165 \mathrm{CE}$ and between $1570 \mathrm{CE}$ and $1720 \mathrm{CE}$, which were interpreted as a consequence of climatic droughts that resulted in the total drying out of the lake (Cañellas-Boltà et al., 2013). The first drought ended during the Medieval Climate Anomaly (MCA), and the second occurred during the Little Ice Age (LIA). The pollen record showed that deforestation did not occur in an abrupt manner but during three main pulses, with no signs of forest regeneration between them (Fig. 7). The first deforestation pulse (450 BCE) coincided with the first appearance of the Neotropical weed Verbena litoralis and the first increase in charcoal, which suggested an early Amerindian presence (likely in small populations) on the island approximately one millennium and a half before Polynesian settlement (Cañellas-Boltà et al., 2013). This deforestation event occurred when the catchment was occupied by a mire, as indicated by lithology and diatom assemblages, suggesting the existence of climates that were dry but not as arid as during the MCA and LIA droughts. The second deforestation pulse (1200 CE) was the most intense and was coeval with an outstanding expansion of grass meadows and verbena populations and an abrupt exacerbation of fires. These changes coincided with increasing lake levels, as recorded by diatoms, 
suggesting wetter climates after the MCA drought (Fig. 7). The acceleration of fire and forest clearing in such wetter climates suggested that humans were been the main driver responsible for these landscape changes. The third forest-clearing event ( $1475 \mathrm{CE})$ corresponded to the total deforestation of the Raraku catchment and the irreversible establishment of grass meadows, which was also associated with a significant increase in charcoal. Among the three forest declines, only the second could possibly be linked to climate change, as it occurred immediately after the MCA drought, which could have increased forest flammability, thus acting synergistically with anthropogenic burning (Cañellas-Boltà et al. (2013). After the LIA drought, the diatom assemblages suggested maximum lake levels and, hence, the wettest climates of the last 3700 years.

The Rano Aroi core recorded a long period of constant vegetation, consisting of open palm woodlands within a landscape dominated by grass meadows, between 750 BCE and 1250 CE (Rull et al., 2015). However, some minor variations in palm and grass density between $300 \mathrm{BCE}$ and $50 \mathrm{CE}$ and between $600 \mathrm{CE}$ and $1100 \mathrm{CE}$ coincided with significant reversals in geochemical records ( $\mathrm{C}$ and $\mathrm{N}$ isotopes), indicating the occurrence of drier (but not arid) climates. The second dry phase coincided with the MCA drought reported at Rano Raraku (Cañellas-Boltà et al., 2013). After $1250 \mathrm{CE}$, a progressive densification of palm woodland to more closed forests took place, coinciding with the appearance of aquatic vegetation, indicating an increase in the water table that was likely due to a wetter climate, which would have favored forest growth. These dense forests were abruptly removed within a century (1520 CE to $1620 \mathrm{CE}$ ), coinciding with the first appearance of charcoal, which suggested anthropogenic burning (Rull et al., 2015). The geochemical proxies were consistent with a third dry phase similar to the first two between 1520 CE and 1700 CE, coinciding with the LIA drought documented at Rano Raraku (CañellasBoltà et al., 2013).

The Rano Kao record began at approximately $1000 \mathrm{CE}$, when the catchment was covered by open palm woodlands, which suggested that forests were already being disturbed (Seco et al., 2019). The further deforestation of Rano Kao was gradual but spiked with three pulses of acceleration at approximately $1070 \mathrm{CE}, 1410 \mathrm{CE}$ and $1600 \mathrm{CE}$, followed by further regeneration trends except after the third pulse, which was irreversible. The first pulse occurred during the MCA drought, which suggested a potential influence of climate. The second pulse ( $1410 \mathrm{CE})$ coincided with a small charcoal peak and the first continuous appearance of coprophilous fungi, notably Sporormiella, suggesting the onset of continuous anthropogenic disturbance. Palms almost disappeared but slightly recovered until the third declining pulse (1600 CE), when charcoal and Sporormiella dramatically increased, roughly coinciding with the first phases of the LIA drought, which could have contributed to fire exacerbation. Seco et al. (2019) suggested that humans were present in the Rano Kao catchment from the beginning of the record but in dispersed or occasional populations. Human presence became more or less permanent by 1410 CE but remained sparse. The catchment was fully deforested and disturbed by larger human populations by 1600 CE. At the same time, the pollen of Apiaceae (likely Apium) species increased abruptly and remained constant until at least $1700 \mathrm{CE}$, which suggested the cultivation of these plants around the lake.

\section{Contributions of paleoecology to the reconstruction of Easter Island's prehistory}

This section summarizes the usefulness of the paleoecological knowledge described above for a more holistic understanding of Easter Island's prehistory. The discussion is focused on the following aspects: (i) the possibility of the early discovery and/or settlement of the island before Polynesian colonization; (ii) the climatic changes that occurred during the last millennium that could have affected the island's ecology and society; (iii) the spatiotemporal deforestation patterns and their possible natural and anthropogenic drivers; and (iv) the possible influence of climatic droughts on prehistoric cultural aspects, with emphasis on the shift from the ancestor worship to the Birdman Cult. 


\subsection{Discovery and settlement}

The first well-dated evidence of deforestation and meadow expansion associated with a fire event, which was suggestive of human disturbance, was found in Rano Kao sediments between 50 CE and 100 CE (Butler and Flenley 2010). The authors noted that this would be contrary to most archaeological reconstructions and discussed other possibilities for the origin of fire, such as spontaneous combustion, a combination of lightning and dry climates, and volcanic eruptions. However, Butler \& Flenley (2010) noted that charcoal concentrations never returned to background levels after the 50-100 CE exacerbation, suggesting continuous, rather than episodic disturbance. The conclusion was that this evidence should not be dismissed, but further studies would be needed for a sound interpretation in terms of human influence. This conclusion, however, has been maintained by the same authors several years after (Flenley \& Butler, 2018).

In Rano Kao, Horrocks et al. (2013) found a high concentration of charcoal fragments associated with banana phytoliths in sediments corresponding to 1730-910 BCE. According to these authors, this could be interpreted in terms of anthropogenic forest clearing by fire and associated agriculture, but the dates were confusing, as they were much older than the expected settlement of eastern Polynesia (Kirch et al., 2010; Wilmshurst et al., 2011). Horrocks et al. (2013) did not dismiss the possible existence of dating problems due to contamination, but they maintained the robustness of their age-depth model.

In Rano Raraku, the coincidence of forest clearing with a charcoal increase and the first appearance of the Neotropical weed Verbena litoralis suggested that some Amerindian culture could have discovered Easter Island by 450 BCE (Cañellas-Boltà et al., 2013). The disturbance caused was minimal and was compatible with the presence of small scattered ephemeral or intermittent human populations, as previously suggested by Mann et al. (2003).

In Rano Aroi, Horrocks et al. (2015) reported the presence of Sisyrinchium, another American invader taxon, since at least 410-630 CE. These authors were very cautious and stated that "...we report this evidence and note that there is no clear reason to dismiss it, nor there is a clear case to accept it. Specifically, we are unaware of any Rapa Nui archaeological excavations or other evidence that provide conclusive support for prehistoric Amerindian presence". However, the case of Sisyrinchium is compatible with that of Verbena regarding the possible early Amerindian presence on Easter Island.

The absence of archaeological evidence for these early discoveries could be explained by the phenomenon of "evidence clearing" (Rull, 2020a), according to which erosion, rising sea levels and/or further colonizers may destroy or hide the meager terrestrial evidence left by scarce and scattered populations (Stevenson et al., 2000; Flenley \& Bahn, 2011). Paleoecological evidence contained in lake/swamp sediments, however, is less susceptible to clearing and can provide evidence that is absent in the archaeological record, as has been documented on other oceanic islands (e.g., Rull et al., 2017). The paleoecological findings summarized above could represent the first steps towards obtaining robust evidence of human presence on Easter Island before Polynesian settlement and cannot be neglected, as they are based on robust age-depth models and reliable taxonomic identification. However, the situation can be improved by the incorporation of direct evidence of human presence obtained using biomarkers such as DNA and specific fecal lipids, among others (e.g., Bull et al., 2002; D'Anjou et al., 2012; Hofreiter et al., 2012; Rawlence et al., 2014; Parducci et al., 2017). The field of biomarker analysis in lake sediments is currently in full swing, and it is hoped that future paleoecological studies on Easter Island can take advantage of this.

\subsection{Climatic changes}

Paleoecological research on Easter Island has also provided local paleoclimatic information using biotic and abiotic proxies. To date, only changes in the moisture balance have been recorded, notably, the 
occurrence of two centennial-scale droughts separated by a phase of wet climates (Fig. 8). The MCA drought was recorded in Rano Raraku between 500 and 1170 CE, when the lake dried out and remained in that condition for more than six centuries (Cañellas-Boltà et al., 2013). The same event was recorded in Rano Aroi between 600 and 1100 CE (Rull et al., 2015), but in this case, the moisture reduction was less intense, likely due to the higher humidity of the highlands compared to the lowlands (Puleston et al., 2017). This MCA drought was coeval with the Classic Maya Collapse (ca. 900 CE) in Central America, which was attributed to a series of prolonged droughts that led to the ultimate demise of this civilization (Haug et al., 2003). An ensuing moisture increase was recorded between approximately 1100-1170 and 1520-1570 CE in both Rano Raraku and Rano Aroi (Cañellas-Boltà et al., 2013; Rull et al., 2015). The LIA drought occurred between 1570 and 1720 CE, when Lake Raraku dried out again (Fig. 8). In Rano Aroi, this drought was more difficult to detect due to the masking effects of human disturbance from $1520 \mathrm{CE}$ onwards. The LIA drought coincided with the so-called " $17^{\text {th }}$ century crisis" in tropical Asia, characterized by droughts, famines and large-scale economic and political disruption (Grove \& Adamson, 2018). Before the intense MCA and LIA droughts, the climates were drier than at present (but not arid) in both Raraku and Aroi (Cañellas-Boltà et al., 2013; Rull et al., 2015). After the LIA drought, Lake Raraku reached its present-day levels, which suggested the return of wetter climates.

The potential climatic mechanism causing the MCA and LIA droughts can be summarized as a southern shift of the humid subtropical storm track and the emplacement of the dry South Pacific Anticyclone over Easter Island, likely forced by ENSO fluctuations (Mann et al., 2008; Sáez et al., 2009). A potential role for volcanic eruptions occurring in the Pacific Islands has also been discussed, but it is still too soon for a definite answer (Margalef et al., 2018). The most remarkable eruptions of the last millennia corresponded to the Samalas (1257 CE) and Kuwae volcanoes (1453 CE) - located on Lombock Island, near Bali, and the Melanesian Vanuatu Archipelago, respectively - both of which occurred during the Easter Island humid phase between the MCA and LIA droughts (Fig. 8). There is still much work to do to achieve a sound understanding of the recent paleoclimatology of Easter Island, especially in terms of resolution and spatial patterns. At present, the Rano Kao core utilized above to reconstruct deforestation trends (Seco et al., 2019) is being studied for high-resolution paleoclimatic reconstruction using the isotopic composition of plant leaf waxes as a precipitation proxy. Other organic biomarkers are available (Eglington \& Eglington, 2008; Castañeda \& Schouten, 2011; Maloney et al., 2019; Sear et al., 2020) and should be tested on Easter Island for a more complete paleoclimatic reconstruction.

\subsection{Spatiotemporal deforestation patterns}

Paleoecological records have shown that the deforestation of Easter Island was heterogeneous in time and space, as forest clearing occurred at different times and different rates across the island (Fig. 9). The first deforestation event of the last millennium occurred in Rano Kao by $1050 \mathrm{CE}$, during the MCA drought, and was probably caused by synergistic climate-human effects (Seco et al., 2019). At that time, the Rano Raraku forests and the Rano Aroi open woodlands were still untouched. The next forest clearing event occurred in Rano Raraku at approximately 1200 CE, immediately after the MCA drought, under moderate but sustained fire pressure (Cañellas-Boltà et al. (2013). The occurrence of wetter climates that are more favorable for forest growth (Fig. 8) suggests that this deforestation pulse was of anthropogenic origin. Forest retreat was continuous although fires did not increase significantly, which suggests the existence of positive feedback amplifying forest responses to a sustained fire incidence. At the same time, the Rano Kao forests were recovering, likely due to favorable climates and the absence of human pressure (Seco et al., 2019). This forest regeneration was interrupted by another deforestation event (1350 CE), likely anthropogenic in nature (Seco et al., 2019).

Rano Aroi continued to be devoid of humans, and the significant forest expansion recorded between approximately 1300 and 1500 CE was likely due to the occurrence of wetter climates (Rull et al., 2015). The Rano Raraku forests disappeared after a final deforestation event by $1450 \mathrm{CE}$, coinciding with significant fire exacerbation, supporting anthropogenic causes (Cañellas-Boltà et al., 2013). At the same 
time, human pressure declined in Rano Kao, and its forests experienced a new regeneration trend, although this was less intense than the previous regeneration (Seco et al., 2019). At the same time, Rano Aroi was truly forested for the first time, and its forests became the densest and most extensive on the island. This forest densification could likely have been due to wetter climates and the absence of human activities in Rano Aroi. However, the situation changed by $1570 \mathrm{CE}$, when a sudden deforestation event completely removed these forests (Rull et al., 2015). This coincided with intense fire exacerbation, suggesting anthropogenic causes; however, the LIA drought would have acted synergistically by favoring forest flammability and preventing regeneration. The last deforestation event on the island irreversibly removed the Rano Kao forests by $1600 \mathrm{CE}$, coinciding with the highest human occupation of this crater (Seco et al., 2019).

Taken globally, the intensification of deforestation between approximately 1200 CE and the total disappearance of forests by approximately $1600 \mathrm{CE}$ coincides with the phase of increased forest clearing formerly proposed by Mann et al. (2003) and Mieth \& Bork (2015), after a phase of low-intensity ecological impact. However, the detailed reconstruction described here, based on continuous sedimentary records from the three basins suitable for paleoecological study, significantly increases the spatiotemporal resolution and provides much more detail about the patterns, processes and possible causes of the different forest removal and regeneration events. Further efforts should emphasize the study of proxies for human presence such as coprophilous fungi and specific molecular biomarkers of human presence. The use of paleoclimatic biomarkers and an increase in the temporal resolution are also recommended.

\subsection{Cultural responses to climatic droughts}

During the MCA and LIA droughts, Rano Raraku was totally dry, and freshwater availability was critical for human life. Polynesians arrived on the island during the MCA drought, when Lake Raraku was devoid of water but its surroundings were still forested (Fig. 9). At that time, the only permanent freshwater sources were Lake Kao and the Aroi swamp. Not surprisingly, the Rano Kao forests were the first to be disturbed (Seco et al., 2019). The LIA drought and the second drying out of Rano Raraku occurred when Rano Raraku was already deforested (Cañellas-Boltà et al., 2013). The situation was more critical than that during the MCA drought, as the Rapanui population was more numerous, and Rano Raraku - the site of the moai quarry and a central point for the Rapanui culture by that time - was likely transformed into a badland devoid of freshwater and forests (Rull, 2020a, b). Again, the only permanent freshwater bodies were Lake Kao and the Aroi swamp, which began to be fully exploited and were totally deforested by 1600 CE (Rull et al., 2015; Seco et al., 2019). Human pressure significantly intensified in Rano Kao, as manifested by the dramatic increase in paleoecological indicators of human presence and agricultural activity along the lakeshores immediately below the ceremonial village of Orongo (Horrocks et al., 2012b, 2013; Seco et al., 2019). This possibly favored the emergence of the Birdman cult and the shift of the Rapanui cultural center from Rano Raraku to Rano Kao (Fig. 9).

The causes of the shift from the ancestor worship to the Birdman Cult remain controversial, but some potential explanations may be suggested from the above observations. One is the search for freshwater. Another is that the Rano Kao rocks were not suitable for moai carving. Indeed, the Kao crater is composed of hard basalt and was one of the quarries from which the tools to carve the softer Raraku tuff were obtained (Gioncada et al., 2010). Only 13 of the ca. 1000 known moai are made of basalt (Van Tilburg, 1994). Robinson \& Stevenson (2017) suggested that the shift from the moai cult to the Birdman cult corresponded to a territorial restructuring in response to soil nutrient depletion in interior lands, probably due to deforestation and a long period of dryness, which is in agreement with the above paleoecological observations. It has also been proposed that the shift from to the Birdman cult corresponded to a change from a rigid, hierarchical and dynasty-based society, which flourished during the phase of relatively stable wet climates, to a more dynamic sociopolitical organization, which represented a strategy that was better adapted to changing environmental conditions. 
An additional freshwater source for the prehistoric Rapanui has been proposed, involving coastal seeps fed by the groundwater system (Brosnan et al., 2018). To obtain water from these seeps, the ancient Rapanui used to excavate pits parallel to the shoreline, known as puna, which are still preserved at several sites near prehistoric habitation sites. All waters found in these coastal seeps today are brackish, which led Brosnan et al. (2018) to suggest that the Rapanui drank brackish water. As rain is the only freshwater source for recharging the groundwater system, its supply should have been drastically reduced during the LIA drought, which suggests that the salinity of coastal seeps could have been higher than it is today. Therefore, it is unlikely that coastal seeps would have been major freshwater sources for circumventing the LIA freshwater crisis, which lasted for a century and a half, representing approximately six human generations.

\section{Towards an integrated view}

The prehistory of Easter Island is a complex subject that cannot be properly understood using simplifications that favor either one or another deterministic theory. Rather, natural and anthropogenic drivers of ecological and cultural change, along with their potential feedback and synergy, should be considered to obtain a more objective explanation of the available evidence. Ideally, such a synthesis should be conducted by interdisciplinary teams including open-minded researchers from a range of disciplines. Each of these disciplines provides part of the same puzzle, and we should learn how to assemble these parts together instead of claiming to know the absolute truth using only our own particular, always incomplete, set of pieces. Here, the available paleoclimatic and paleoecological findings from the last millennia are placed in a cultural chronological framework following the archaeological, ethnographic and historical knowledge summarized in section 2 to pave the way towards a more integrated view (Fig. 10). This should be considered as an attempt to show the potential contribution of paleoecology to an integrated view of Easter Island's prehistory. The new information and the varied approaches and views arising from a wide range of disciplines compiled in this book will provide the basis for improving the preliminary synthesis presented here. The EHLFS (EnvironmentalHuman-Landscape Feedbacks and Synergies) framework (Rull, 2018), together with the multiple working hypotheses approach (Chamberlin, 1965) and the strong inference method of hypothesis testing (Platt, 1964), may provide a suitable methodological framework to accommodate multidisciplinary knowledge into a coherent holistic perspective. The first steps in the application of this methodology to the case of Easter Island have already been made (Rull, 2018, 2020a), but there is still much room for improvement. Another possibility for addressing the problem could be the Human Ecodynamics (HE) approach (Fitzhugh et al., 2019) but this topic will be discussed in more depth in the final chapter of the book dedicated specifically to the integration multidisciplinary evidence on Easter Island.

\section{Acknowledgments}

No funding was received for developing and writing this chapter. The author's research on Easter Island was funded by the Spanish Ministry of Education and Science, project GEOBILA (CGL2007-60932/BTE; Alberto Sáez, principal investigator) and the Catalan Agency for the Management of University and Research Grants (AGAUR), project GREB (2017-SGR415; Joan Vallès, principal investigator). Discussions with members of the GEOBILA project are gratefully acknowledged, especially with Núria Cañellas-Boltà, Santiago Giralt, Olga Margalef, Sergi Pla-Rabes and Alberto Sáez. Other authors and coauthors of papers on Easter Island's paleoecology are also acknowledged, especially Roberto Bao, Hilary Birks, John Birks, Maarten Blaauw, Raymond Bradley, William D'Andrea, Encarni Montoya, Matthew Prebble, Irantzu Seco and Blas Valero-Garcés. However, the views expressed herein are the sole responsibility of the author. Critical revisions by Núria Cañellas-Boltà, Patrick Nunn and Christopher Stevenson contributed to improve the original manuscript. 
Table 1. Characteristics of radiocarbon-dated peat and lake sediment cores obtained in Easter Island, according to the original references. The main proxies studied in each core are also indicated. ND = No Data. Publication lag refers to the years elapsed between coring and the first detailed publication of the original results.

Rano Aroi (270 05' 37.37" N-109o 22' 26.50"; 433 m elevation)

\begin{tabular}{|l|l|l|l|l|l|l|}
\hline Core & $\begin{array}{l}\text { Water } \\
\text { Depth } \\
\text { (m) }\end{array}$ & $\begin{array}{l}\text { Core } \\
\text { Length } \\
\text { (m) }\end{array}$ & Year & $\begin{array}{l}\text { Coring } \\
\text { device }\end{array}$ & Main proxies studied & References \\
\hline ARO1 & 0.00 & $\sim 11.50$ & 1977 & Russian & $\begin{array}{l}\text { Lithostratigraphy, elemental } \\
\text { analysis, pollen and spores, } \\
\text { charcoal }\end{array}$ & $\begin{array}{l}\text { Flenley (1979), Flenley \& } \\
\text { King (1984), Flenley et al. } \\
\text { (1991) }\end{array}$ \\
\hline ARO 06-01 & 0.00 & 13.90 & 2006 & UWITEC & $\begin{array}{l}\text { Facies description, mineralogy, } \\
\text { elemental analysis, stable isotops, } \\
\text { plant and animal macrofossils, } \\
\text { pollen and spores }\end{array}$ & $\begin{array}{l}\text { Margalef (2014), Margalef } \\
\text { et al. (2013, 2014) }\end{array}$ \\
\hline ARO 08-02 & 0.00 & 4.00 & 2008 & Russian & $\begin{array}{l}\text { Facies description, mineralogy, } \\
\text { elemental analysis, stable isotops, } \\
\text { plant and animal macrofossils, } \\
\text { pollen and spores }\end{array}$ & $\begin{array}{l}\text { Margalef (2014), Margalef } \\
\text { et al. (2015, 2014), Rull et }\end{array}$ \\
\hline RA2 & 0.00 & 8.00 & 1997 & Livingstone & $\begin{array}{l}\text { Lithostratigraphy, diffuse spectral } \\
\text { reflectance, pollen and spores }\end{array}$ & Peteet et al (2013) \\
\hline RA & 0.00 & 4.00 & 2009 & Russian & $\begin{array}{l}\text { Lithostratigraphy, magnetic } \\
\text { susceptibility, plant and animal } \\
\text { macrofossils, charcoal, pollen and } \\
\text { spores, biosilicates, phytoliths, } \\
\text { starch }\end{array}$ & Horrocks et al. (2015) \\
\hline RAI* & 0.00 & 2.11 & 2009 & Russian & $\begin{array}{l}\text { Lithostratigraphy, magnetic } \\
\text { susceptibility, plant and animal } \\
\text { macrofossils, charcoal, pollen and } \\
\text { spores, biosilicates, starch }\end{array}$ & Horrocks et al. (2015) \\
\hline
\end{tabular}

*Rano Aroi Iti (see Fig. 1)

Rano Kao (27ㅇ 11' 12.57" N-109 26'06.75"; 107 m elevation)

\begin{tabular}{|l|l|l|l|l|l|l|}
\hline Core & $\begin{array}{l}\text { Water } \\
\text { Depth } \\
\text { (m) }\end{array}$ & $\begin{array}{l}\text { Core } \\
\text { Length } \\
(\mathbf{m})\end{array}$ & Year & Coring device & Main proxies studied & References \\
\hline KAO1 & 0.00 & $\sim 11.00$ & 1977 & Russian & $\begin{array}{l}\text { Lithostratigraphy, elemental } \\
\text { analysis, pollen and spores, } \\
\text { charcoal }\end{array}$ & $\begin{array}{l}\text { Flenley (1979), Flenley } \\
\text { \& King (1984), Flenley et } \\
\text { al. (1991) }\end{array}$ \\
\hline 1 & ND & 20.00 & 2009 & Russian + Living & $\begin{array}{l}\text { Lithostratigraphy, magnetic } \\
\text { susceptibility, plant and animal } \\
\text { macrofossils, charcoal, pollen } \\
\text { and spores, starch }\end{array}$ & Horrocks et al. (2013) \\
\hline 2 & ND & $\sim 6.00$ & 2009 & Russian + Living, & $\begin{array}{l}\text { Lithostratigraphy, phytoliths, } \\
\text { pollen and spores, starch }\end{array}$ & Horrocks et al (2012b) \\
\hline 3 & ND & $\sim 5.00$ & 2009 & Russian + Living & $\begin{array}{l}\text { Lithostratigraphy, phytoliths, } \\
\text { pollen and spores, starch }\end{array}$ & Horrocks et al (2012b) \\
\hline 4 & ND & $\sim 12.00$ & 2009 & Russian + Living & $\begin{array}{l}\text { Lithostratigraphy, phytoliths, } \\
\text { pollen and spores, starch }\end{array}$ & Horrocks et al (2012b) \\
\hline 5 & ND & $\sim 7.00$ & 2009 & Russian + Living, & $\begin{array}{l}\text { Lithostratigraphy, phytoliths, } \\
\text { pollen and spores, starch }\end{array}$ & Horrocks et al (2012b) \\
\hline KAO2 & 10.50 & 20.85 & 1983 & Russian & $\begin{array}{l}\text { Lithostratigraphy, elemental } \\
\text { analysis, pollen and spores, } \\
\text { charcoal }\end{array}$ & $\begin{array}{l}\text { Butler \& Flenley (2001), } \\
\text { Butler \& Flenley (2010), } \\
\text { Butler et al. (2004), } \\
\text { Flenley (1996) }\end{array}$ \\
\hline KAO3 (KAO0 & 10.50 & 21.50 & 2005 & Russian + Living & $\begin{array}{l}\text { Magnetic susceptibility, oxygen } \\
\text { isotopes, pollen and spores }\end{array}$ & Gossen (2007, 2011) \\
\hline
\end{tabular}




\begin{tabular}{|l|l|l|l|l|l|l|}
\hline KAO08-03 & ND & 2.20 & 2008 & Russian & $\begin{array}{l}\text { Lithostratigraphy, pollen and } \\
\text { spores, charcoal, non-pollen } \\
\text { palynomorphs (NPP) }\end{array}$ & $\begin{array}{l}\text { Rull et al. (2018), } \\
\text { Seco et al. (2019) }\end{array}$ \\
\hline
\end{tabular}

Rano Raraku (270 07' 19.79" - 109 17' 20.66”; 80 m elevation)

\begin{tabular}{|c|c|c|c|c|c|c|}
\hline Core & $\begin{array}{l}\text { Water } \\
\text { Depth } \\
\text { (m) }\end{array}$ & $\begin{array}{l}\text { Core } \\
\text { Length } \\
\text { (m) }\end{array}$ & Year & $\begin{array}{l}\text { Coring } \\
\text { device }\end{array}$ & Main proxies studied & References \\
\hline RRA3 & 0.00 & $\sim 12.00$ & 1977 & Russian & $\begin{array}{l}\text { Lithostratigraphy, elemental } \\
\text { analysis, pollen and spores, } \\
\text { charcoal }\end{array}$ & $\begin{array}{l}\text { Flenley (1979), Flenley \& King } \\
\text { (1984), Flenley et al. (1991) }\end{array}$ \\
\hline RRA4 & 2.80 & $\sim 17.20$ & 1983 & Russian & $\begin{array}{l}\text { Lithostratigraphy, mineralogy, } \\
\text { elemental analysis }\end{array}$ & Flenley et al. (1991) \\
\hline RRA5 & ND & 13.40 & 2005 & Livingstone & Pollen and spores & Azizi \& Flenley (2008) \\
\hline SW & 2.00 & $\sim 3.40$ & 1990 & Piston & $\begin{array}{l}\text { Magnetic properties, plant and } \\
\text { animal microfossils (pollen, } \\
\text { cladocera, ostracoda, diatoms), } \\
\text { pigments }\end{array}$ & Dumont et al. (1998) \\
\hline 1 & 6.00 & $\sim 1.00$ & 1998 & Gravity & $\begin{array}{l}\text { Lithostratigraphy, magnetic } \\
\text { susceptibility, organic matter, } \\
\text { charcoal, pollen and spores }\end{array}$ & Mann et al. $(2003,2008)$ \\
\hline 2 & 6.00 & $\sim 1.00$ & 1998 & Gravity & Organic matter & Mann et al. $(2003,2008)$ \\
\hline RAR01 & ND & $\sim 5.70$ & 2006 & UWITEC & $\begin{array}{l}\text { Magnetic susceptibility, facies } \\
\text { description, elemental analysis, } \\
\text { mineralogy }\end{array}$ & Sáez et al. (2009) \\
\hline RAR02 & ND & $\sim 6.80$ & 2006 & UWITEC & $\begin{array}{l}\text { Magnetic susceptibility, facies } \\
\text { description, elemental analysis, } \\
\text { mineralogy }\end{array}$ & Sáez et al. (2009) \\
\hline RAR03 & ND & $\sim 13.80$ & 2006 & UWITEC & $\begin{array}{l}\text { Magnetic susceptibility, facies } \\
\text { description, elemental analysis, } \\
\text { mineralogy, plant and animal } \\
\text { macrofossils, pollen and spores }\end{array}$ & $\begin{array}{l}\text { Sáez et al. (2009), Cañellas- } \\
\text { Boltà (2014), Cañellas-Boltà et } \\
\text { al. }(2012,2014,2016)\end{array}$ \\
\hline RAR04 & ND & $\sim 6.00$ & 2006 & UWITEC & $\begin{array}{l}\text { Magnetic susceptibility, facies } \\
\text { description, elemental analysis, } \\
\text { mineralogy }\end{array}$ & Sáez et al. (2009) \\
\hline RAR05 & ND & $\sim 13.20$ & 2006 & UWITEC & $\begin{array}{l}\text { Magnetic susceptibility, facies } \\
\text { description, elemental analysis, } \\
\text { mineralogy }\end{array}$ & Sáez et al. (2009) \\
\hline RAR07 & ND & $\sim 12.80$ & 2006 & UWITEC & $\begin{array}{l}\text { Magnetic susceptibility, facies } \\
\text { description, elemental analysis, } \\
\text { mineralogy, plant and animal } \\
\text { macrofossils, pollen and spores }\end{array}$ & $\begin{array}{l}\text { Sáez et al. (2009), Cañellas- } \\
\text { Boltà (2014), Cañellas-Boltà } \\
\text { et al. }(2012,2014,2016)\end{array}$ \\
\hline RAR08 & ND & $\sim 12.60$ & 2006 & UWITEC & $\begin{array}{l}\text { Magnetic susceptibility, facies } \\
\text { description, elemental analysis, } \\
\text { mineralogy }\end{array}$ & $\begin{array}{l}\text { Sáez et al. (2009), Cañellas- } \\
\text { Boltà (2014), Cañellas-Boltà et } \\
\text { al. (2013) }\end{array}$ \\
\hline Lake & 2.60 & 2.25 & 2009 & Livingstone & $\begin{array}{l}\text { Lithostratigraphy, plant } \\
\text { macrofossils, pollen and spores, } \\
\text { phytoliths, starch }\end{array}$ & Horrocks et al. (2012a) \\
\hline
\end{tabular}




\section{References}

Azizi, G., Flenley, J.R., 2008. The last glacial maximum climatic conditions on Easter Island. Quat. Int. 184, 166-176.

Bahn, P., Flenley, J., 1992. Easter Island, Earth Island. Tames \& Hudson, London.

Boersema, J.J., 2015. The Survival of Easter Island. Dwinling Resources and Cultural Resilience. Cambridge University Press, Cambridge.

Brosnan, T., Becker, M.W., Lipo, C.P., 2018. Coastal groundwater discharge and the ancient inhabitants of Rapa Nui (Easter Island), Chile. Hydrogeol. J. 27, 519-534.

Bull, I.D., Lockheart, M.J., Elhmmali, M.M., Roberts, D.J., Evershed, R.P., 2002. The origin of faeces by means of biomarker detection. Environ. Int. 27, 647-654.

Butler, K.R. \& Flenley, J.R., 2001. Further pollen evience from Easter Island. in: Stevenson, C.M., Lee, G., Morin, F.J. (Eds.), Pacific 2000. Proceedings of the Fifth International Conference on Easter Island and the Pacific, Easter Island Foundation, Los Osos, pp. 79-86.

Butler, K.R., Flenley, J.R., 2010. The Rano Kau 2 pollen diagram: palaeoecology revealed. Rapa Nui J. 24, 5-10.

Butler, K., Prior, C.A., Flenley, J.R., 2004. Anomalous radiocarbon datesfrom Easter Island. Radiocarbon 46, 395-420.

Cañellas-Bolta, N., 2014. Vegetation Dynamics in Relation to Climate Changes, Geological Processes and Human Impact at Easter Island since the Last Glacial. Paleoecological Study of Sediments from Lake Raraku. PhD Dissertation, University of Barcelona, Spain.

Cañellas-Boltà, N., Rull, V., Sáez, A., Margalef, O., Giralt, S., Pueyo, J.J., Birks, H.H., Birks, H.J.B., PlaRabes, S., 2012. Macrofossils in Raraku Lake (Easter Island) integrated with sedimentary and geochemical records: towards a palaeoecological synthesis of the last 34,000 years. Quat. Sci. Rev. 34, 113-126.

Cañellas-Boltà, N., Rull, V., Sáez, A., Margalef, O., Bao, R., Pla-Rabes, S., Blaauw, M., Valero-Garcés, B., Giralt, S., 2013. Vegetation changes and human settlement of Easter Island during the last millennia: a multiproxy study of the Lake Raraku sediments. Quat. Sci. Rev. 72, 36-48.

Cañellas-Boltà, N., Rull, V., Sáez, A., Prebble, M., Margalef, O., 2014. First records and potential paleoecological significance of Dianella (Xanthorrhoeaceae), an extinct representative of the native flora of Easter Island. Veget. Hist. Archaeobot. 23, 331-338.

Cañellas-Boltà, N., Rull, V., Sáez, A., Margalef, O., Bao, R., Pla-Rabes, S., Valero-Garcés, B., Giralt, S., 2016. Vegetation dynamics at Raraku Lake catchment (Easter Island) during the past 34,000 years. Palaeogeogr. Palaeoclimatol. Palaeoecol. 446, 55-69.

Castañeda, I.S., Schouten, S., 2011. A review of molecular organic proxies for examining modern and ancient lacustrine environments. Quat. Sci. Rev. 30, 2851-2891.

Caviedes, C.N., Waylen, P.R., 2011. Rapa Nui: a climatically constrained island? Rapa Nui J. 25, 7-23.

Chamberlin, T.C., 1965. The method of multiple working hyptheses. Science 148, 754-759.

Cummings, L.S., 1998. A review of recent pollen and phytolith studies from vrious contexts on Easter Island, in: Stevenson, C.M., Lee, G., Morin, F.J. (Eds.), Easter Island in Pacific Context. Proceedings of the Fourth International Conference on Easter Island and East Polynesia. Easter Island Foundation, Los Osos, pp. 100-106.

D’Anjou, R.M., Bradley, R.S., Balascio, N.L., Finkelstein, D.B., 2012. Climate impacts on human settlement and agricultural activities in northern Norway revealed hrough sediment biogeochemistry. Proc. Natl. Acad. Sci. USA 109, 20332-20337.

Diamond, J., 2005. Collapse. How societies choose to fail or survive. Allen Lane, London.

Dransfield, J., Flenley, J.R., King, S.M., Harkness, D.D., Rapu, S., 1984. A recently extinct palm from Easter Island. Nature 312, 750-752.

Dumont, H.J., Cocquyt, C., Fortugne, M., Arnold, M., Reyss, J.L., Bloemendal, J., Oldfield, F., Steenbergen C.L.M., Korthals, H.J., Zeeb, B.A., 1998. The end of moai quarrying and its effect on Lake Rano Raraku, Easter Island. J. Paleolimnol. 20, 409-422. 
Eglington, T.I., Eglington, G., 2008. Molecular proxies for paleoclimatology. Earth Planet. Sci. Lett. 275, 116.

Fischer, S.R., 2005. Island at the End of the World. The Turbulent History of Easter Island. Reaktion Books, London.

Fitzhugh, B., Butler, V.L., Etnier, M.A. 2019. Human acodynamics: A perspective for the study of longterm change in socioecological systems. J. Archaeol. Sci. Rep. 23, 1077-1094.

Flenley, J.R., 1979. Stratigraphic evidence of environmental change on Easter Island. Asian Perspect. 22, 33-40.

Flenley, J.R., 1996. Further evidence of vegetational change on Easter Island. South Pacific St. 16, 135141.

Flenley, J.R., 1998. New data and new thoughts about Rapa Nui, in: Stevenson, C.M., Lee, G., Morin, F.J. (Eds.), Easter Island in Pacific Context. Proceedings of the Fourth International Conference on Easter Island and East Polynesia. Easter Island Foundation, Los Osos, pp. 125-128.

Flenley, J.R., Bahn, P.G., 2003. The enigmas of Easter Island. Oxford Univ. Press, Oxford.

Flenley, J.R., Bahn, P.G., 2011. Hunt, Terry and Carl Lipo. The Statues tha Walked. Unravelling the mystery of Easter Island. Rapa Nui J. 25, 60-62.

Flenley, J.R., Butler, K., 2018. New interpretations of pollen data from Easter Island, in: Haoa Cardinali, S., Ingersoll, K.B., Stevenson, C.M. (Eds.), Cultural and Environmental Change on Rapa Nui. Routledge, London, pp. 32-58, pp. 74-86.

Flenley, J.R., King, S., 1984. Late Quaternary pollen records from Easter Island. Nature 307, 47-50.

Flenley, J.R., King, A.S.M, Jackson, J., Chew, C., Teller, J.T., Prentice, M.E., 1991. The Late Quaternary vegetational and climatic history of Easter Island. J. Quat. Sci. 6, 85-115.

Genz, J., Hunt, T.L., 2003. El Niño/southern oscillations and Rapa Nui prehistory. Rapa Nui J. 17, 7-14.

Gioncada, A., González-Ferran, O., Lezzerini, M., Mazzuoli, R., Bisson, M., Rapu, S.A., 2010. The volcanic rocks of Easter Island (Chile) and their use for the moai sculptures. Eur. J. Mineral. 22, 855-867.

Gossen, C., 2007. Report: the mystery lies in the Scirpus. Rapa Nui J. 21, 105-110.

Gossen, C., 2011. Deforestation, Drought and Humans: New Discoveries of the Late Quaternary Paleoenvironment of Rapa Nui (Easter Island). PhD Dissertation, Portland State University, USA.

Grove, R., Adamson, G., 2018. El Niño chronology and the Little Ice Age, in: Grove, R., Adamson, G. (Eds.), El Niño in World History. Palmgrave Macmillan, London, pp. 49-79.

Haberle, S.G., Chepstow-Lusty, A., 2000. Can climate influence cultural development? A view through time. Environ Hist 6, 349-369.

Haug, G., Günther, D., Peterson, L.C., Sigman, D.M., Hughen, K.A., Aeschlimann, B., 2003. Climate and the collapse of Maya civilization. Science 299, 1731-1735.

Herrera, C., Custodio, E., 2008. Conceptual hydrogeological model of volcanic Easter Island (Chile) after chemical and isotopic surveys. Hydrogeol. J. 16, 1329-1348.

Heyerdahl, T., 1952. American Indians in the Pacific: the Theory Behind the Kon-Tiki Expedition. Allen \& Unwin, London.

Heyerdahl, T., 1989. Easter Island. The Mystery Solved. Random House, New York.

Heyerdahl, T., Ferdon, E., 1961. Reports of the Norwegian Archaeological Expedition to Easter Island and the East Pacific, Volume 1: Archaeology of Easter Island. Rand McNally, New York.

Hofreiter, M., Collins, M., Stwrat, J.R., 2012. Ancient biomolecules in Quaternary palaeoecology. Quaternary Science Reviews 33, 1-13.

Horrocks, M., Wozniak, J.A., 2008. Plant microfossil analysis reveals disturbed forest and a mixed-crop, dryland production system at Te Niu, Easter Island. J. Archaeol. Sci. 35, 126-142.

Horrocks, M., Baisden, W.T., Flenley, J., Feek, D., González-Nualart, L., Haoa-Cardinali, S., Edmunds Gorman, T., 2012a. Fossil plant remains at Rano Raraku, Easter Island's statue quarry: evidence for past elevated lake level and ancient Polynesian agriculture. J. Paleolimnol. 46, 767-783.

Horrocks, M., Baisden, W.T., Nieuwoudt, M.K., Flenley, J., Feek, D., González Nualart, L., Haoa-Cardinali, S., Edmunds Gorman, T., 2012b. Microfossils of Polynesian cultigens in lake sediment cores from Rao Kau, Easter Island. J. Paleolimnol. 47, 185-204. 
Horrocks,M., Marra,M., Baisden, W.T., Flenley, J., Feek, D., González-Nualart, L., Haoa-Cardinali, S., Edmunds Gorman, T., 2013. Pollen, phytoliths, arthropods and high-resolution ${ }^{14} \mathrm{C}$ sampling from Rano Kau, Easter Island: evidence for late quaternary environments, ant (formicidae) distributions and human activity. J. Paleolimnol. 50, 417-432.

Horrocks, M., Baisden,W. T., Harper, M. A., Marra, M., Flenley, J., Feek, D., Haoa-Cardinali, S., Keller, E.D., González Nualart, L., Edmunds Gorman, T., 2015. A plant microfossil record of Late Quaternary environments and human activity from Rano Aroi and surroundings, Easter Island. J. Paleolimnol. 54, 279-303.

Horrocks, M., Baisden, T., Flenley, J., Feek, D., Love, C., Haoa-Cardinali, S., González Nualart, L., Edmunds Gorman, T., 2016. Pollen, phytolith and starch analyses of dryland soils from Easter Island (Rapa Nui) show widespread vegetation clearance and Polynesian-introduced crops. Palynology 41, 339350.

Hunt, T.L., 2006. Rethinking the fall of Easter Island. New evidence points to and alternative explanation for a civilization's collapse. Am. Sci. 94, 412-419.

Hunt, T.L., 2007. Rethinking Easter Island's ecological catastrophe. J. Archaeol. Sci. 34, 485-502.

Hunt, T.L., Lipo, C.P., 2006. Late colonization of Easter Island. Science 311, 1603-1606.

Hunter-Anderson, R.L., 1998. Human vs. climatic impacts at Rapa Nui, Did people really cut down all those trees?, in: Stevenson, C.M., Lee, G., Morin, F.J. (Eds.), Easter Island in Pacific Context. Proceedings of the Fourth International Conference on Easter Island and East Polynesia. Easter Island Foundation, Los Osos, pp. 95-99.

Jarman, C.L., Larsen, T., Hunt, T.L., Lipo, C.P., Solsvik, R., Wallsgrove, N., Ka'apu-Lyons, C., Close, H.G., Popp, B.N., 2017. Diet of the prehistoric population of Rapa Nui (Easter Island, Chile) shows environmental adaptation and resilience. Am. J. Phys. Anthropol. 164, 343-361.

Jones, T.L., Storey, A.A., Matisoo-Smith, E., Ramírez-Aliaga, J.M., 2011. Polynesians in America. PreColumbian Contact with the New World. Altamira Press, Landham.

Kirch, P.V., 1984. The Evolution of the Polynesian Chiefdoms. Cambridge University Press, Cambridge.

Kirch, P.V., 2010. Peopling of the Pacific: a holistic anthropological perspective. Annu. Rev. Anthropol. 39, 131-148.

Lipo, C.P., Hunt, T.L., 2016. Chronology and Easter Island prehistory, in: Stefan, V.H., Gill, G.W. (Eds.), Skeletal Biology of the Ancient Rapanui (Easter Islanders). Cambridge University Press, Cambridge, pp. 39-65.

Maclntyre, F., 2001. ENSO, climate variability and the Rapanui. Part II, oceanography and the Rapanui. Rapa Nui J. 15, 83-94.

Maloney, A.E., Nelson, D.B., Richey, J.N., Prebble, M., Sear, D.A., Hassall, J.D., Langdon, P.G., Croudace, I.W., Zawadzki, A., Sachs, J.P., 2019. Recosntructing precipitation in the tropical South Pacific from dinosterol ${ }^{2} \mathrm{H} /{ }^{1} \mathrm{H}$ ratios in lake sediment. Gecohim. Cosmochim. Acta 245, 190-206.

Mann, D., Chase, J., Edwards, J., Beck, W., Reanier, R., Mass, M., 2003. Prehistoric destruction of the primeval soils and vegetation of Rapa Nui (Isla de Pascua, Easter Island), in: Loret, J., Tanacredi, J.T. (Eds.), Easter Island. Scientific Exploration into the World's Environmental Problems in Microcosm. Kluwer Academic/Plenum, New York, pp. 133-153.

Mann, D., Edwards, J., Chase, J., Beck, W., Reanier, R., Mass, M., Finney, B., Loret, J., 2008. Drought, vegetation change, and human history on Rapa Nui (Isla de Pascua, Easter Island). Quat. Res. 69, $16-28$.

Margalef, O., 2014. The Last 70 kyr of Rano Aroi (Easter Island, $27^{\circ} \mathrm{S}$ ) Peat Record: New Insights for the Central Pacific Paleoclimatology. PhD Dissertation, University of Barcelona, Spain.

Margalef, O., Cañellas-Boltà, N., Pla-Rabes, S., Giralt, S., Pueyo, J.J., Joosten, H., Rull, V., Buchaca, T., Hernández, A., Valero-Garcés, B.L., Moreno, A., Sáez, A., 2013. A 70,000 year geochemical and palaeoecological record of climatic and environmental change from Rano Aroi peatland (Easter Island). Glob. Planet. Change 108, 72-84.

Margalef, O., Martínez-Cortizas, A., Kylander, M., Pla-Rabes, S., Cañellas-Boltà, N., Pueyo, J.J., Sàez, A., Valero-Garcés, B., Giralt, S., 2014. Environmental processes in Rano Aroi (Easter Island) peat 
geochemistry forced by climate variability during the last 70 kyr. Palaeogeogr. Palaeoclimatol. Palaeoecol. 414, 438-450.

Margalef, O., Álvarez-Gómez, J.S., Pla-Rabes, S., Cañellas-Boltà, N., Rull, V., Sáez, A., Geyer, A., Peñuelas, J., Sardans, J., Giralt, S., 2018. Revisiting the role of high-enegry Pacific events in the environmental and cultural history of Easter Island (Rapa Nui). Geogr. J. 184, 310-322.

Martinsson-Wallin, H., Crockford, S.J., 2002. Early settlement of Rapa Nui (Easter Island). Asian Perspect. 40, 244-278.

McCall, G. 1993. Little Ice Age, some speculations for Rapanui. Rapa Nui J. 7, 65-70.

Mieth, A., Bork, H.R., 2005. History, origin and extent of soil erosion on Easter Island (Rapa Nui). Catena 63, 244-260.

Mieth, A., Bork, H.R., 2010. Humans, climate or introduced rats -which is to blame for the woodland destruction on prehistoric Rapa Nui (Easter Island)? J. Archaeol. Sci. 37, 417-426.

Mieth, A., Bork, H.R., 2015. Degradation of resources and successful land-use management on prehistoric Rapa Nui: two sides of the same coin, in: Cauwe, N., De Dapper, M. (Eds.), International Conference Easter Island: Collapse or transformation? A State of the Art. Royal Academy of Overseas Science, Royal Museums of Art and History, Belgian Science Policy Office, Brussels, pp. 91-113.

Mieth, A., Bork, H.R., 2017. A vanished landscape - phenomena and eco-cultural consequences of extensive deforestation in the prehistory of Rapa Nui, in: Haoa Cardinali, S., Ingersoll, K.B., Stevenson, C.M. (Eds.), Cultural and Environmental Change on Rapa Nui. Routledge, London, pp. 32-58.

Mucciarone, D.A., Dunbar, R.B., 2003. Stable iotope record of El Niño-Southern Oscillation events from Easter Island, in: Loret, J., Tanacredi, J.T. (Eds.), Easter Island. Scientific Exploration into the World's Environmental Problems in Microcosm. Kluwer Academic/Plenum, New York, pp. 113-132.

Mulloy, W., 1974. Contemplate the Navel of the World. Américas 26, 25-33.

Mulloy, W., 1979. A preliminary culture-historical research model for Easter Island. In: Echevarría, G., Arana, P. (Eds.), Las Islas Oceánicas de Chile. Univ. Chile, Santiago de Chile, pp. 105-151.

Mulloy, W., 1997. Preliminary culture-historical research model for Easter Island. In: The Easter Island Bulletins of William Mulloy. World Monumets Fund \& Easter Island Foundation, New York \& Houston, pp. 97-111.

Mulrooney, M.A., 2013. An island-wide assessment of the chronology of settlement and land use on Rapa Nui (Easter Island) based on radiocarbon data. J. Archaeol. Sci. 40, 4377-4399.

Nunn, P.D., 2000. Environmental catastrophe in the Pacific Islands around A.D. 1300. Geoarchaeol. 15, 715-740.

Nunn, P.D., 2007. Climate, Environment and Society in the Pacific During the Last Millennium. Elsevier, Amsterdam.

Nunn, P.D., Britton, J.M.R., 2001. Human-environment relationships in the Pacific, Islands around A.D. 1300. Environ. Hist. 7, 3-22.

Orliac, C., 2000. The woody vegetation of Easter Island between the early $14^{\text {th }}$ and the mid-1 $17^{\text {th }}$ centuries AD, in: Stevenson, C.M., Ayres, W.S. (Eds.), Easter Island Archaeology. Research on Early Rapanui Culture, Easter Island Foundation, Los Osos, pp. 211-220.

Orliac, C., Orliac, M., 1998. The disappearance of Easter Island's forest: over-exploitation or climatic catastrophe?, in: Stevenson, C.M., Lee, G., Morin, F.J. (Eds.), Easter Island in Pacific Context. Proceedings of the Fourth International Conference on Easter Island and East Polynesia. Easter Island Foundation, Los Osos, pp. 129-134.

Parducci, L., Bennett, K.D., Ficetota, G.F., Alsos, I.G., Suyama, Y., Wood, J.R., Pedersen, M.W., 2017. The ancient plant DNA in lake sediments. New Phytol. 214, 924-942.

Peiser, B. 2005. From genocide to ecocide, the rape of Rapa Nui. Energy and Environment 16, 513-539.

Peteet, D., Beck, W., Ortiz, J., O'Connell, S., Kurdyla, D., Mann, D., 2003. Rapid vegetational and sediment change from Rano Aroi crater, Easter Island, in: Loret, J., Tanacredi, J.T. (Eds.), Easter Island. Scientific Exploration into the World's Environmental Problems in Microcosm. Kluwer Academic/Plenum, New York, pp. 81-92. 
Pinart, A., 1878. Exploration de l'île de Pâques. Bull. Soc. Géogr. 16, 193-213.

Platt, J.R., 1964. Strong inference. Science 146, 347-353.

Puleston, C.O., Ladefoged, T.N., Haoa, S., Chadwick, O.A., Vitousek, P.M., Stevenson, C.M., 2017. Rain, sun, soil, and sweat: a consideration of population limits on Rapa Nui (Easter Island) beofre European contact. Front. Ecol. Evol. 5, 69.

Rawlence, N.J., Lowe, D.J., Wood, J.R., Young, J.M., Churchman, G.J., Huang, Y.T., Cooper, A., 2014. Using palaeoenvironmental DNA to reconstruct past environments: progresses and prospects. J. Quat. Sci. 29, 610-626.

Robinson, T., Stevenson, C. M., 2017. The cult of the Birdman: religious change at 'Orongo, Rapa Nui (Easter Island). J. Pacif. Archaeol. 8, 88-102.

Roullier, C., Benoit, L., McKey, D.B., Lebot, V., 2013. Historical collections reveal patterns of diffusion of sweet potato in Oceania obscured by modern plant movements and recombination. Proc. Natl. Acad. Sci. USA 110, 2205-2210.

Rull, V., 2016a. Natural and anthropogenic drivers of cultural change at Easter Island: review and new insights. Quat. Sci. Rev. 150, 31-41.

Rull, V., 2016b. The EIRA database: Last Glacial and Holocene radiocarbon ages from Easter Island's sedimentary records. Front Ecol. Evol. 4, 44.

Rull, V. 2018. Strong Fuzzy EHLFS: a general conceptual framework to address past records of environmental, ecological and cultural change. Quaternary 1, 10.

Rull, V., 2019. Human discovery and settlement of the remote Easter Island (SE Pacific). Quaternary 2, 15.

Rull, V. 2020a. Paleoecological Research on Easter Island. Insights on Settlement, Climate Changes, Deforestation and Cultural Shifts. Elsevier, Amsterdam.

Rull, V., 2020b. The deforestation of Easter Island. Biol. Rev. 95, 121-141.

Rull, V. 2020c. Drought, freshwater availability and cultural resilience on Easter Island (SE Pacific) during the Little Ice Age. Holocene 30, 774-780.

Rull, V., Cañellas-Boltà, N., Sáez, A., Margalef, O., Bao, R., Pla-Rabes, S., Valero-Garcés, B., Giralt, S., 2013. Challenging Easter Island's collapse: The need for interdisciplinary synergies. Front. Ecol. Evol. $1,3$.

Rull, V., Cañellas-Boltà, N., Margalef, O., Sáez, A., Pla-Rabes, S., Giralt, S., 2015. Late Holocene vegetation dynamics and deforestation in Rano Aroi: Implications for Easter Island's ecological and cultural history. Quat. Sci. Rev. 126, 219-226.

Rull, V., Cañellas-Boltà, N., Margalef, O., Pla-Rabes, S., Sáez, A. \& Giralt, S., 2016. Three millennia of climatic, ecological and cultural change on Easter Island: a synthetic overview. Front. Ecol. Evol. 4, 29.

Rull, V., Lara, A., Rubio-Inglés, M.J., Giralt, S., Gonçalves, V., Raposeiro, P., Hernández, A., Sánchez-López, G., Vázquez-Loureiro, D, Bao, R., Masqué, P., Sáez, A., 2017. Vegetation and landscape dynamics under natural and anthropogenic forcing on the Azores Islands: A 700-year pollen record from the São Miguel Island. Quat. Sci. Rev. 159, 155-168.

Rull, V., Montoya, E., Seco, I., Cañellas-Boltà, N., Giralt, S., Margalef, O., Pla-Rabes, S., D'Andrea, W., Bradley, R., Sáez, A., 2018. CLAFS, a holistic climatic-ecological anthropogenic hypothesis on Easter Island's deforestation and cultural change: proposals and testing prospects. Front. Ecol. Evol. 6, 32.

Sáez, A., Valero-Garcés, B., Giralt, S., Moreno, A., Bao, R., Pueyo, J.J., Hernández, A., Casas, D., 2009. Glacial to Holocene climate changes in the SE Pacific. The Raraku Lake sedimentary record (Easter Island, $\left.27^{\circ} \mathrm{S}\right)$. Quat. Sci. Rev. 28, 2743-2759.

Sear, D.A., Allen, M.S., Hassall, J.D., Maloney, A.E., Langdon, P.G., Morrison, A.E., Henderson, A.C.G., Mackay, H., Croudace, I.W., Clarke, C., Sachs, J.P., Macdonald, G., Chiverrell, R.C., Leng, M.J., Cisneros-Dozal, L.M., Fonville, T., 2020. Human settlement of East Polynesia earlier, incremental, and coincident with prolonged South Pacific drought. Proc. Natl. Acad. Sic. USA 117, 8813-8819.

Seco, I., Rull, V., Montoya, E., Cañellas-Boltà, N., Giralt, S., Margalef, O., Pla-Rabes, S., D'Andrea, W.J., Bradley, R.S., Sáez, A. 2019. A continuous palynological record of forest clearing at Rano Kao (Easter Island, SE Pacific) during the last millennium: preliminary report. Quaternary 2, 22. 
Smith, C.S., 1961. A temporal sequence derived from certain ahu, in: Heyerdahl, T., Ferdon, E. (Eds.), Reports of the Norwegian Archaeological Expedition to Easter Island and the East Pacific, Volume 1: Archaeology of Easter Island. Allen \& Unwin, London, pp. 181-218.

Steadman, D.W., Vargas, P., Cristino, C., 1994. Stratigraphy, chronology, and cultural context of an early faunal assemblage from Easter Island. Asian Perspect. 33, 79-96.

Stenseth, N.C., Voje, K.L., 2009. Easter Island: climate change might have contributed to past cultural and societal changes. Clim. Res. 39, 111-114.

Stevenson, C.M., Wozniak, J., Haoa, S., 1999. Prehistoric agricultural production on Easter Island (Raoa Nui), Chile. Antiquity 73, 801-812.

Stevenson, C.M., Ramírez, J.M., Haoa, S., Allen, T., 2000. Archaeological investigations at 'Anakena beach and other near-coastal locations, in: Stevenson, C.P., Ayres, W.S. (Eds.), Easter Island Archaeology: Research on Early Rapanui Culture. Easter Island Foundation, Los Osos, pp. 147-172.

Stevenson, C.M., Puleston, C.O., Vitousek, P.M., Chadwick, O.A., Haoa, S., Ladefoged, T.N., 2015. Variation in Rapa Nui (Easter Island) land use indicates producyion and population peaks prior to European contact. Proc. Natl. Acad. Sci. USA 112, 1025-1030.

Thorsby, E., 2007. Evidence of an early Amerindian contribution to the Polynesian gene pool on Easter Island, in: Wallin, P., Martrinsson-Wallin, H. (Eds.), The Gotland Papers. Selected Papers from the VII International Conference on Easter Island and the Pacific. Migration, Identity, and Cultural Heritage. Gotland University Press, Sweden, pp. 285-295.

Thorsby, E., 2016. Genetic evidence of a contribution of Native Americans to the early settlement of Rapa Nui (Easter Island). Front. Ecol. Evol. 4, 118.

Van Tilburg, J. A., 1994. Easter Island: Archaeology, Ecology, and Culture. Smithsonian Inst. Press, Washington.

Vargas, P., Cristino, C., Izaurieta, R., 2006. 1.000 años en Rapa Nui. Cronología del asentamiento. Editorial Universitaria, Santiago de Chile.

Wilmshurst, J.M., Hunt, T.L., Lipo, C.P., Anderson, A.J., 2011. High-precision radiocarbon dating shows recent and rapid initial human colonization of East Polynesia. Proc. Natl. Acad. Sci. USA 108, 18151820.

Wozniak, J.A., 1999. Prehistoric horticultural practices on Easter Island: lithic mulched gardens and field streams. Rapa Nui J. 13, 95-99.

Wozniak, J.A., 2001. Landscapes of food production on Easter Island: successful subsistence strategies, in: Stevenson, C.M., Lee, G., Morin, F.J. (Eds.), Pacific 2000. Proceedings of the Fifth International Conference on Easter Island and the Pacific, Easter Island Foundation, Los Osos, pp. 91-101.

Wozniak, J.A., 2017. Subsistence strategies on Rapa Nui (Easter Island). Prehistoric gardening practices on Rapa Nui and how they related to current farming practices, in: Haoa Cardinali, S., Ingersoll, K.B., Stevenson, C.M. (Eds.), Cultural and Environmental Change on Rapa Nui. Routledge, London, pp. 87-112.

Zizka, G., 1991. Flowering Plants of Easter Island. Palmarum Hortus Francofurtensis, Frankfurt Main. 


\section{Figure captions}

Figure 1. Google Earth images of the paleoecological sites of Easter Island indicating all cores retrieved to date with published results, which constitute the basis for the EIRA radiocarbon database discussed in the text. MQ - Moai Quarry, slopes where most moai were carved. Modified from Rull (2016b).

Figure 2. Number of cores retrieved on Easter Island for paleoecological study and publications derived from these cores during the last four decades (1977-2019). Only publications with original data (Table 3.1) for the cores are considered, and reviews are excluded. Bars represent the actual number of cores and papers (left scale), and dotted lines are the cumulative trends (right scale).

Figure 3. Summary of the general conclusions of Flenley et al. (1991) regarding vegetation, climate and human disturbance at the three coring sites studied. G - Grasses, F - Ferns, Fr - Forest, I - Increasing, M - Moist, S - Slight, T - Transition, W - Warm. Redrawn and modified from Flenley et al. (1991).

Figure 4. Calibrated radiocarbon ages of charcoal from soils overlying the primeval forest soils (blue bars) and the main prehistorical events (orange bars and red arrows). E - European contact, T - Moai toppling. Redrawn and simplified from Mann et al. (2003).

Figure 5. Pollen percentage diagram for the Late Holocene from Rano Kao core 1 (Fig. 1, Table 1). Only dates obtained from totora seeds/fruits are indicated. Redrawn and simplified from Horrocks et al. (2013).

Figure 6. Age-depth models of the continuous and chronologically coherent sedimentary records of the last millennia recovered in Rano Raraku, Rano Aroi and Rano Kao. The dotted lines in the Raraku model at approximately $10 \mathrm{~cm}$ and $20 \mathrm{~cm}$ indicate minor sedimentary gaps (see text for explanation). Redrawn and modified from Rull (2020b).

Figure 7. Summary diagram of the last 3700 years as represented in core RAR08 from Rano Raraku (Fig. 1 , Table 1). Sedimentary gaps are represented as gray bands, indicating the years lacking in each case. Black arrows indicate remarkable events discussed in the text. N.D. - No Data. Redrawn and modified from Cañellas-Boltà et al. (2013).

Figure 8. Reconstructed climatic trends of the last two millennia at Rano Raraku and Rano Aroi. Raw data from Cañellas-Boltà et al. (2013) and Rull et al. (2015). Droughts are highlighted with a gray band. Blue arrows indicate regional volcanic eruptions that occurred during Easter Island's prehistory (KKuwae eruption, S - Samalas eruption) (Margalef et al., 2028). DACP - Dark Ages Cold Period, LIA - Little Ice Age, MCA - Medieval Climate Anomaly, RWP - Roman Warm Period.

Figure 9. Spatiotemporal deforestation patterns of the Rano Aroi, Rano Kao and Rano Raraku areas and their potential drivers after Polynesian settlement. Forest cover was estimated from the palm pollen percentage. The blue arrow indicates the relocation of the cultural core of Rapanui society from Rano Raraku to Rano Kao. Redrawn and modified from Rull (2020a).

Figure 10. Paleoclimatic and paleoecological scenarios of Easter Island during the last two millennia, indicating the main cultural features discussed in this paper. Drought phases are highlighted by gray bands. Blue lines represent the main cultural features, and the bars below indicate the vegetation shifts of each paleoecological site (Aroi, Raraku, Kao). Black bars represent charcoal (ch) occurrence, and the brown bar in Kao represents the presence of coprophilous fungi (cf), especially Sporormiella. Red arrows indicate possible geographical displacements of the Rapanui population. The green arrow indicates European contact (EC), and the blue arrows indicate the Samalas $(\mathrm{S})$ and Kuwae (K) volcanic eruptions. 
DACP - Dark Ages Cold Period, LIA - Little Ice Age, MCA - Medieval Climate Anomaly, RWP - Roman Warm Period. EI - Easter Island. 

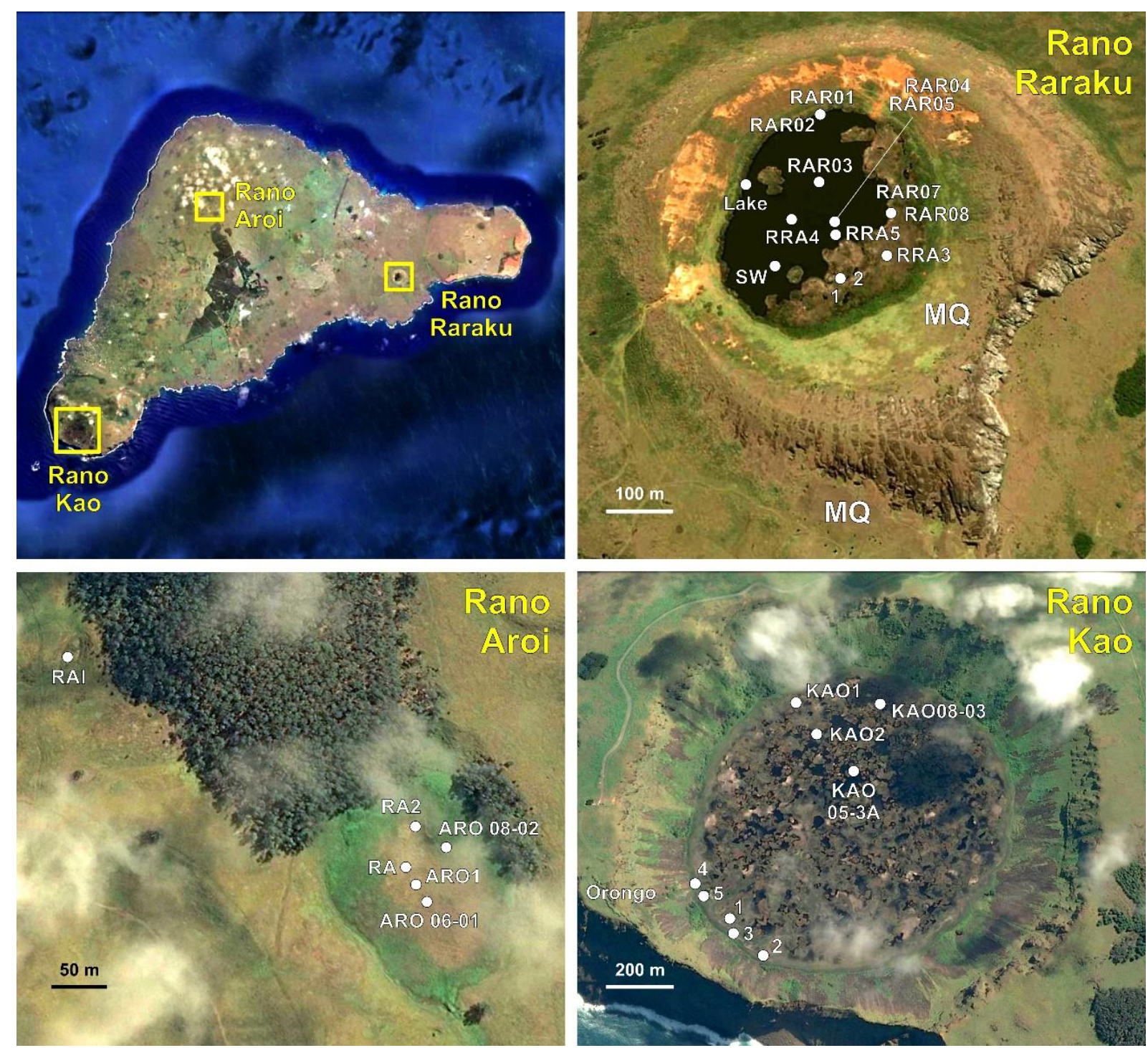

Figure 1 


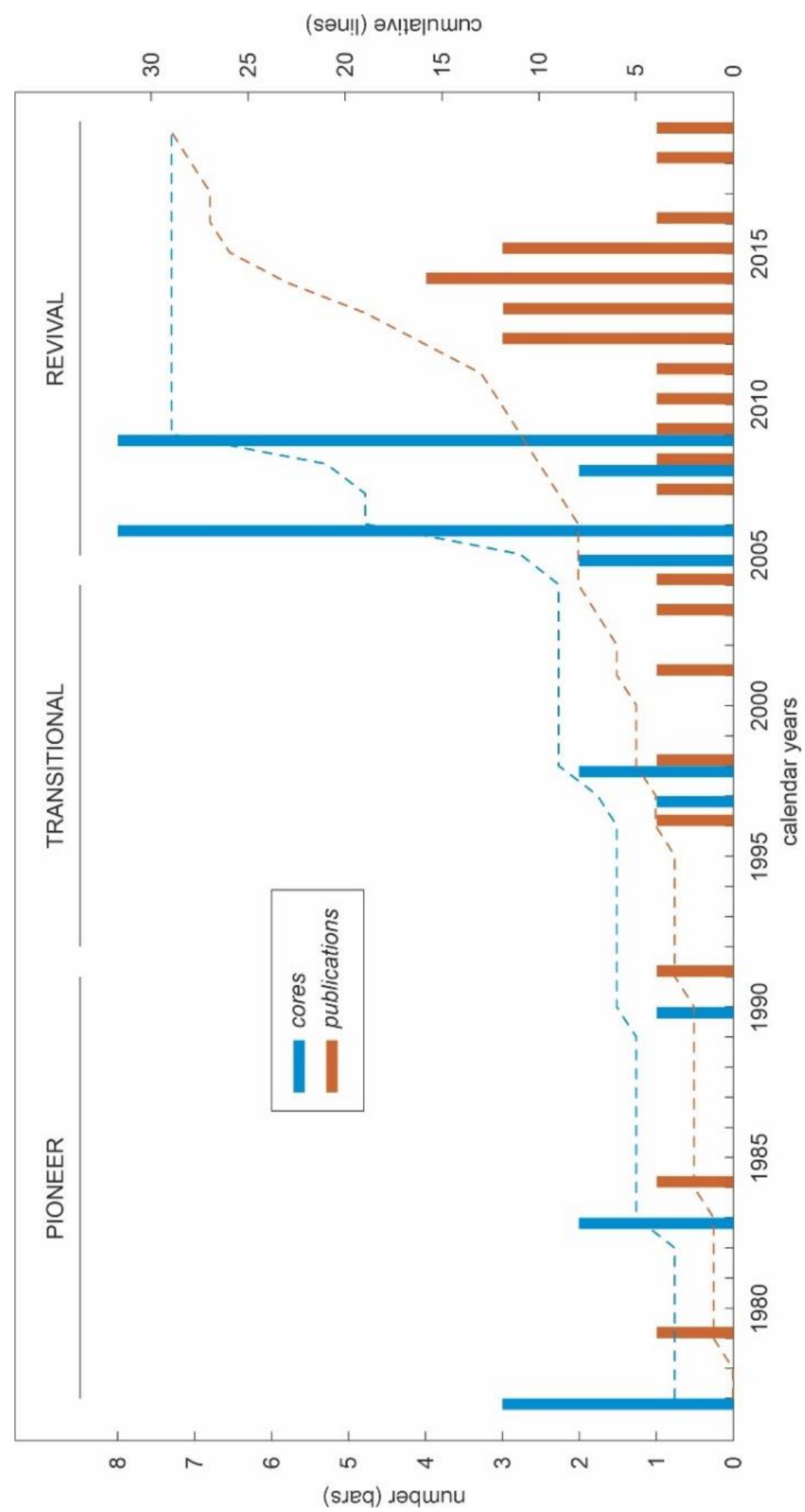

Figure 2 
nyesey ouey !oג ouey oеy ouey

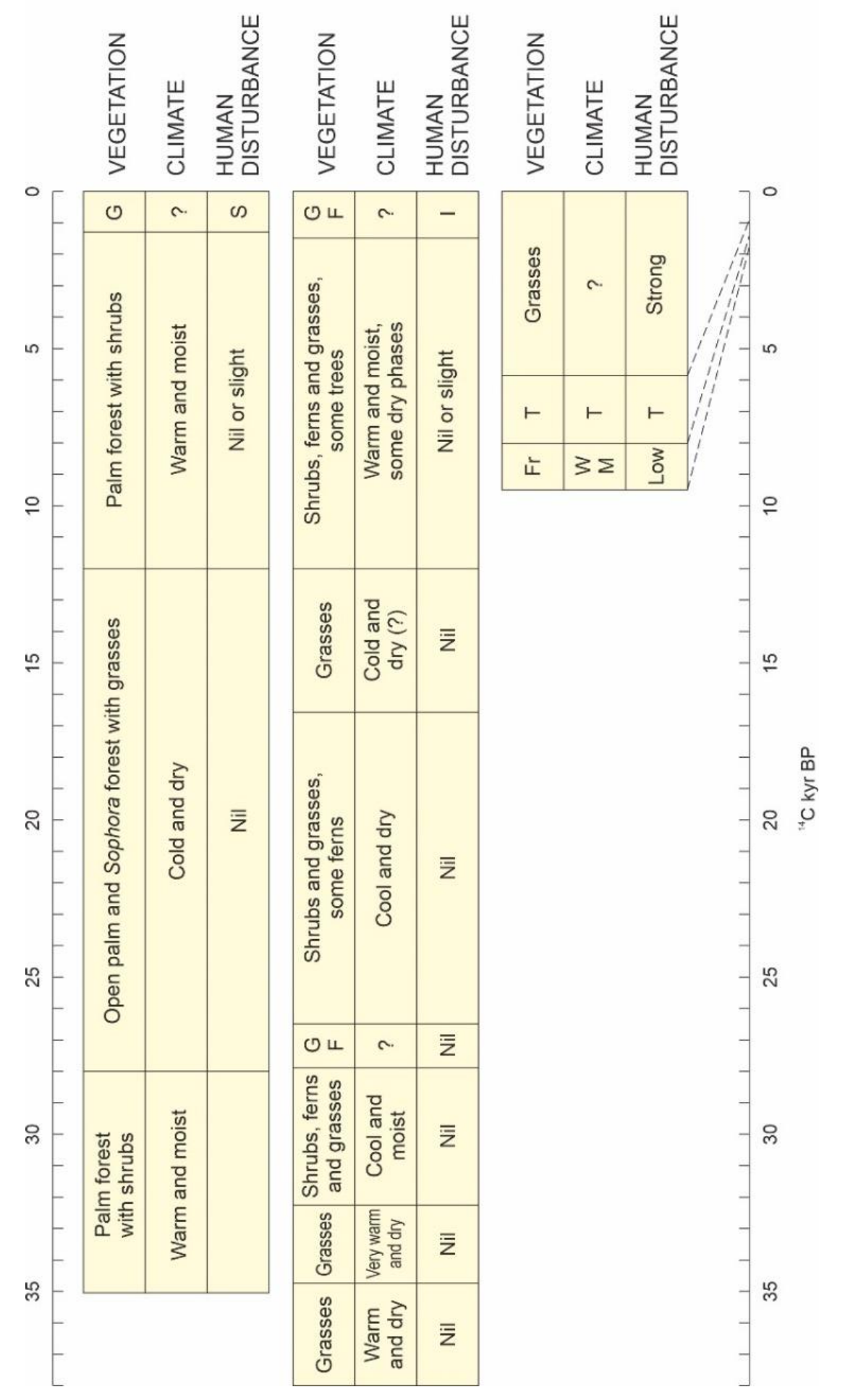

Figure 3 


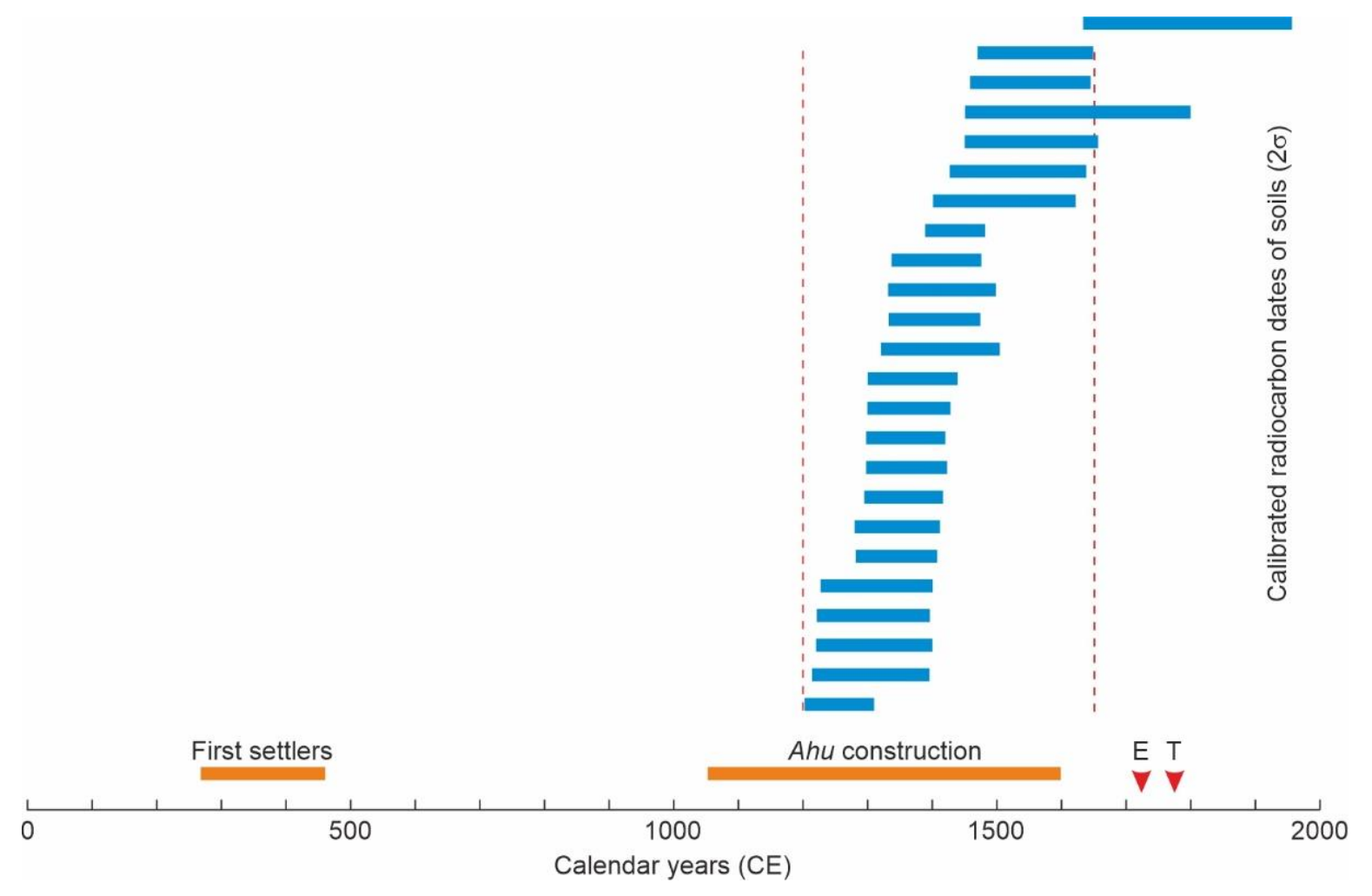

Figure 4 


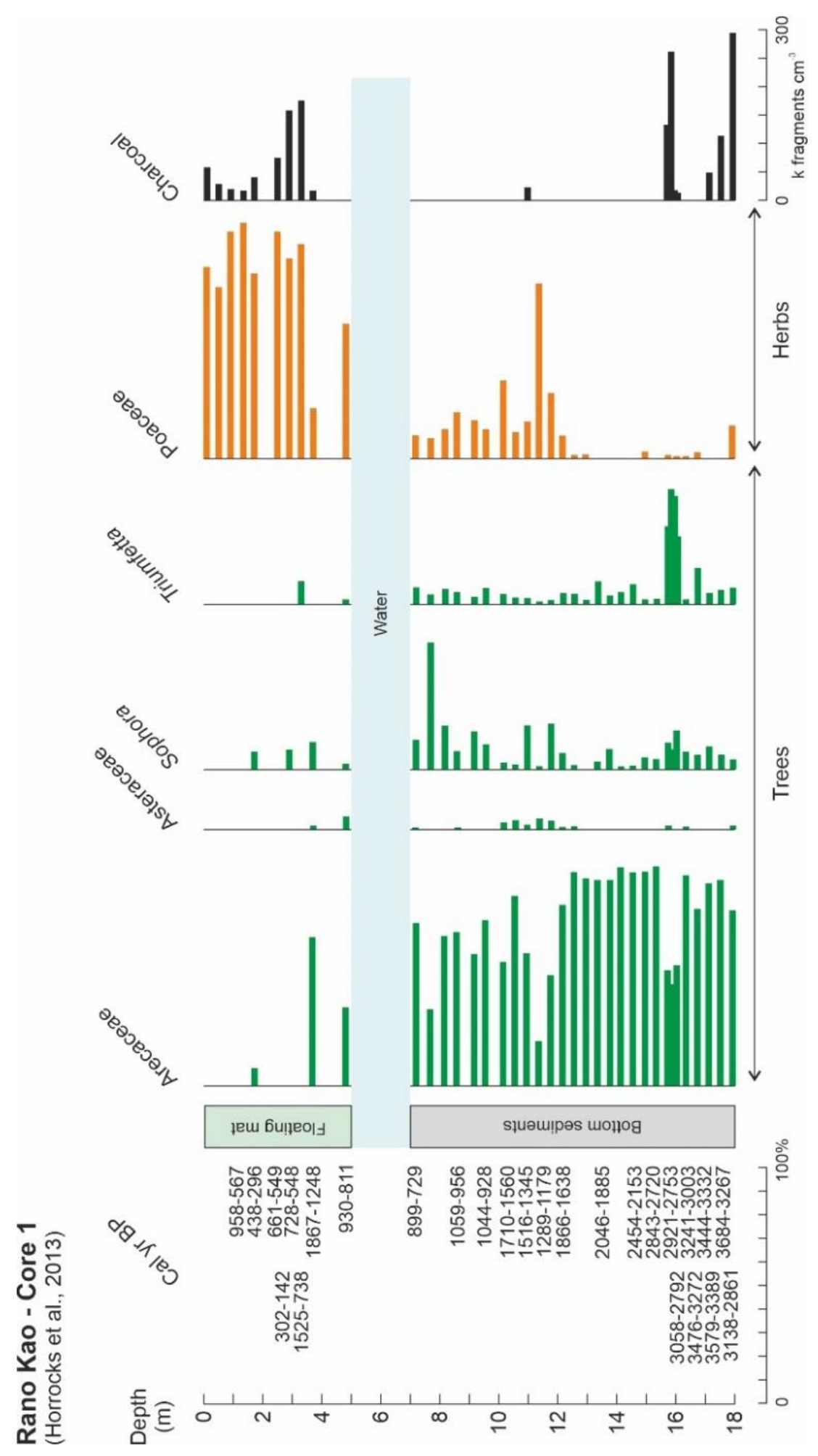

Figure 5 

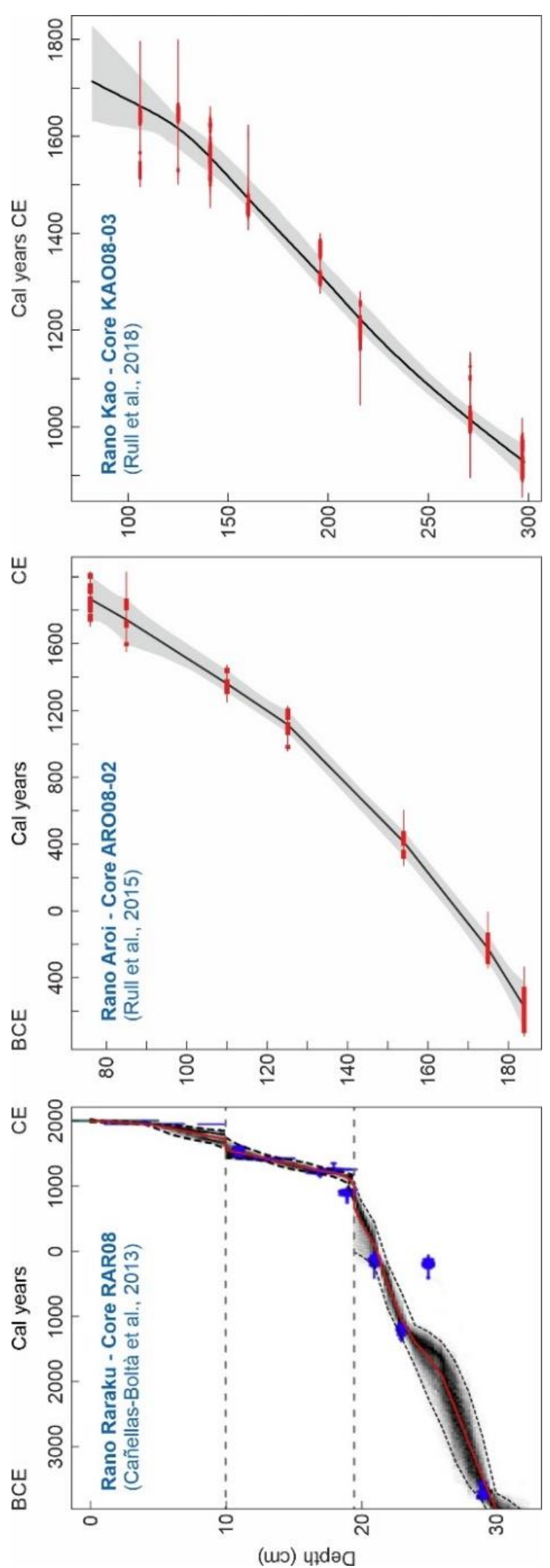

Figure 6 
Rano Raraku - Core RAR08

(Cañellas-Boltà et al., 2013)

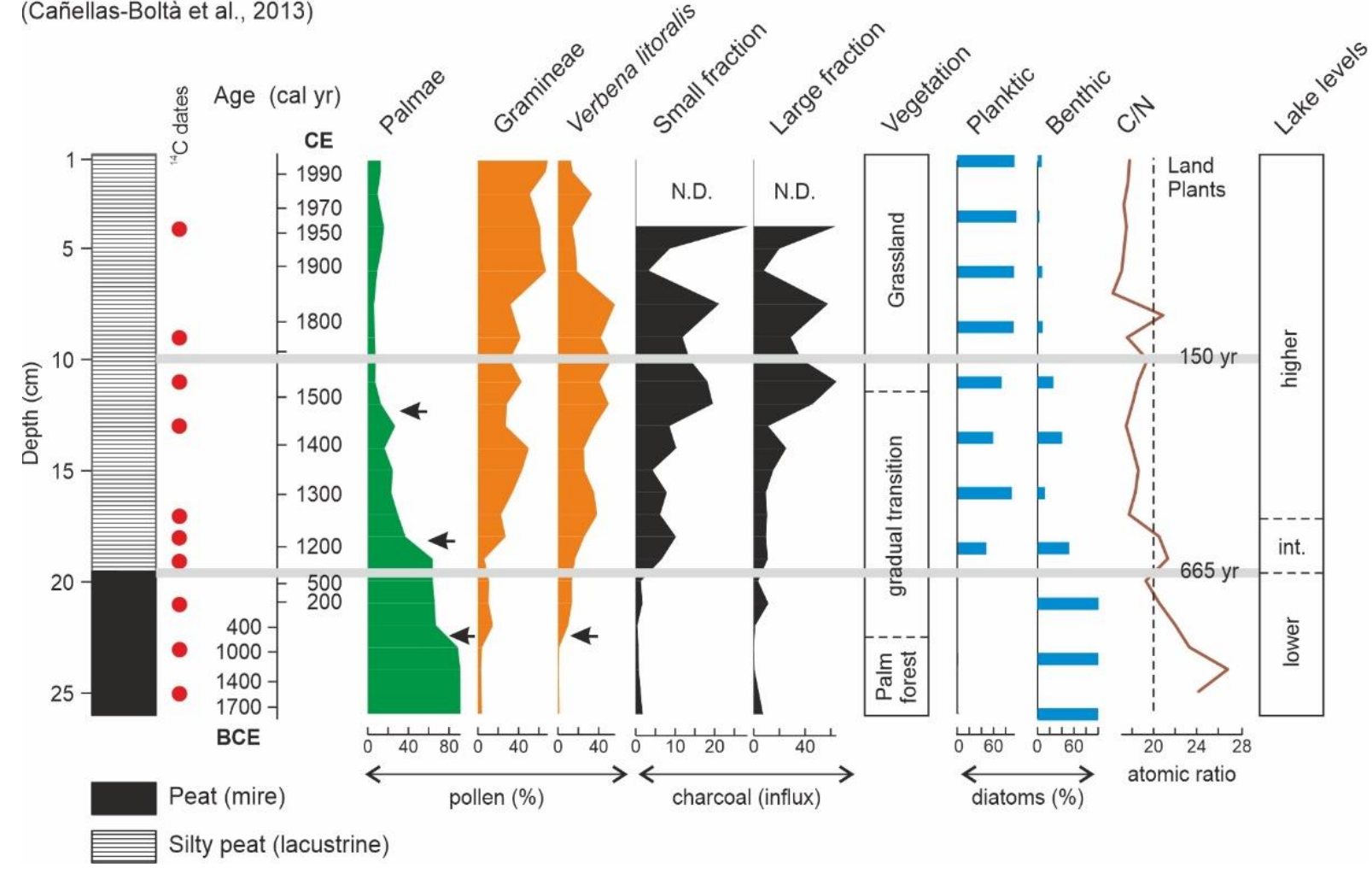

Figure 7 


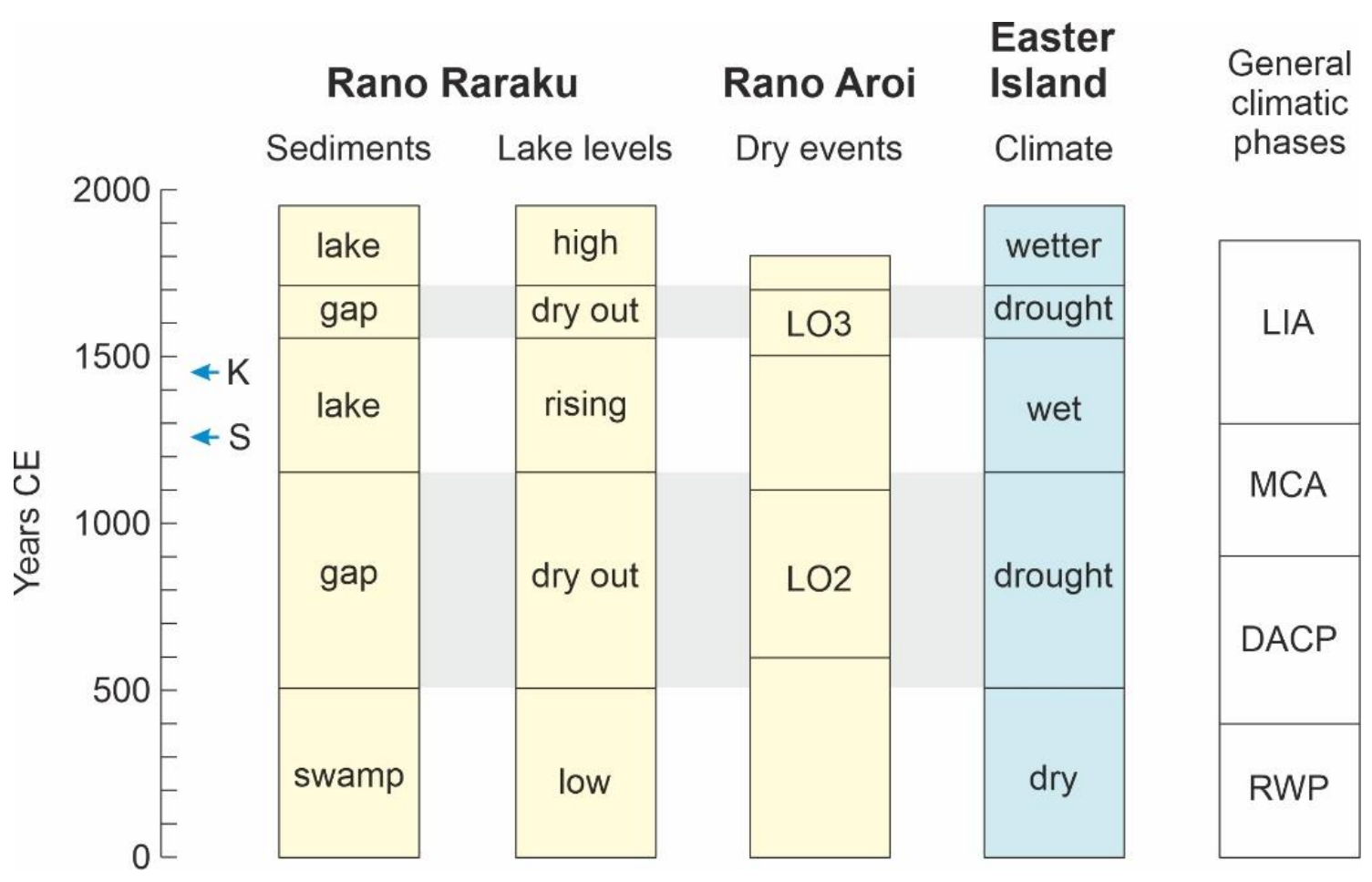

Figure 8 
15
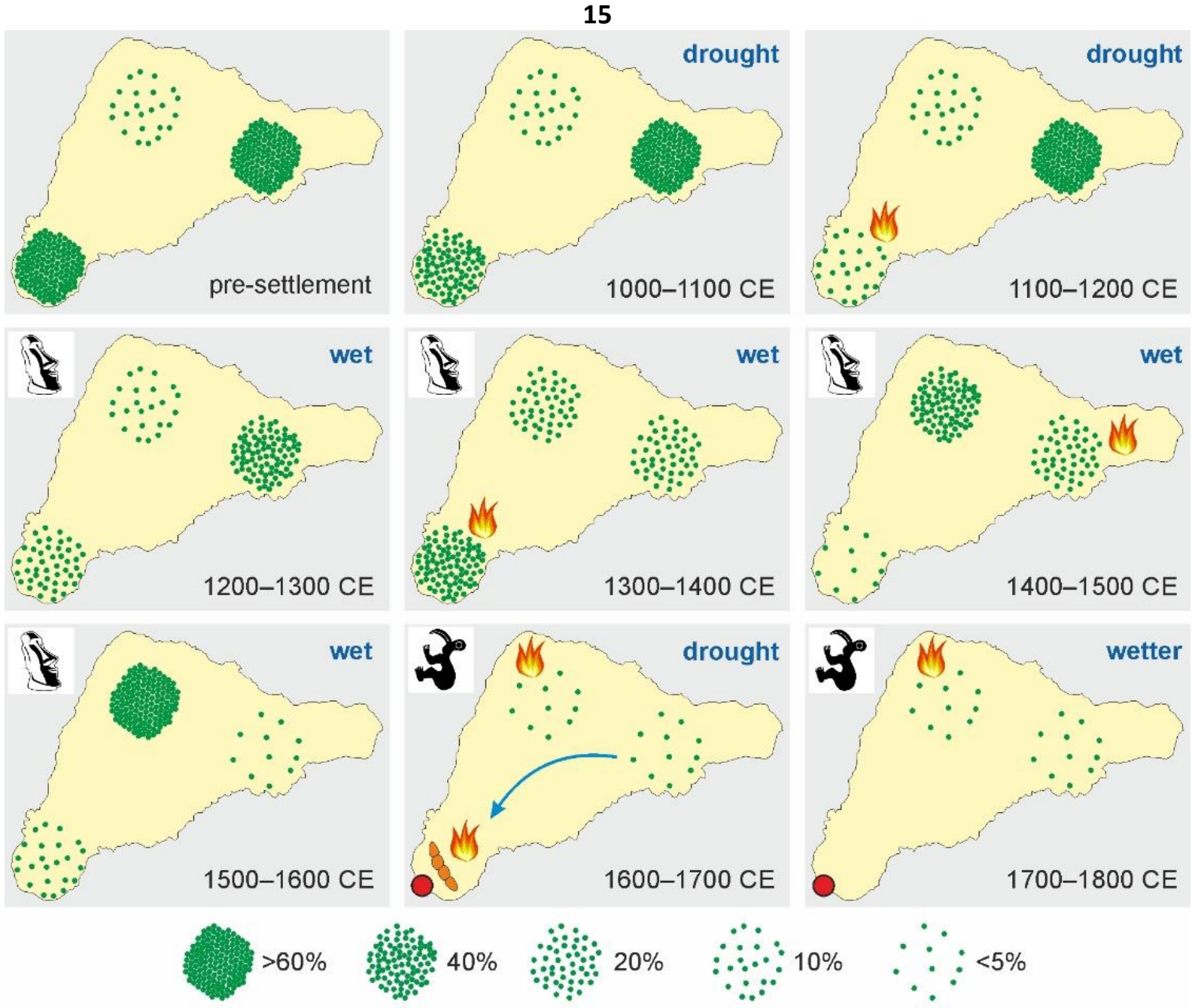

$20 \%$

$\therefore \therefore 10 \%$
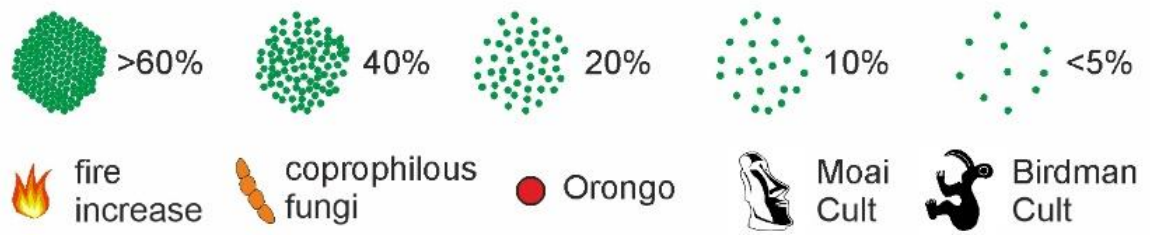

Figure 9 


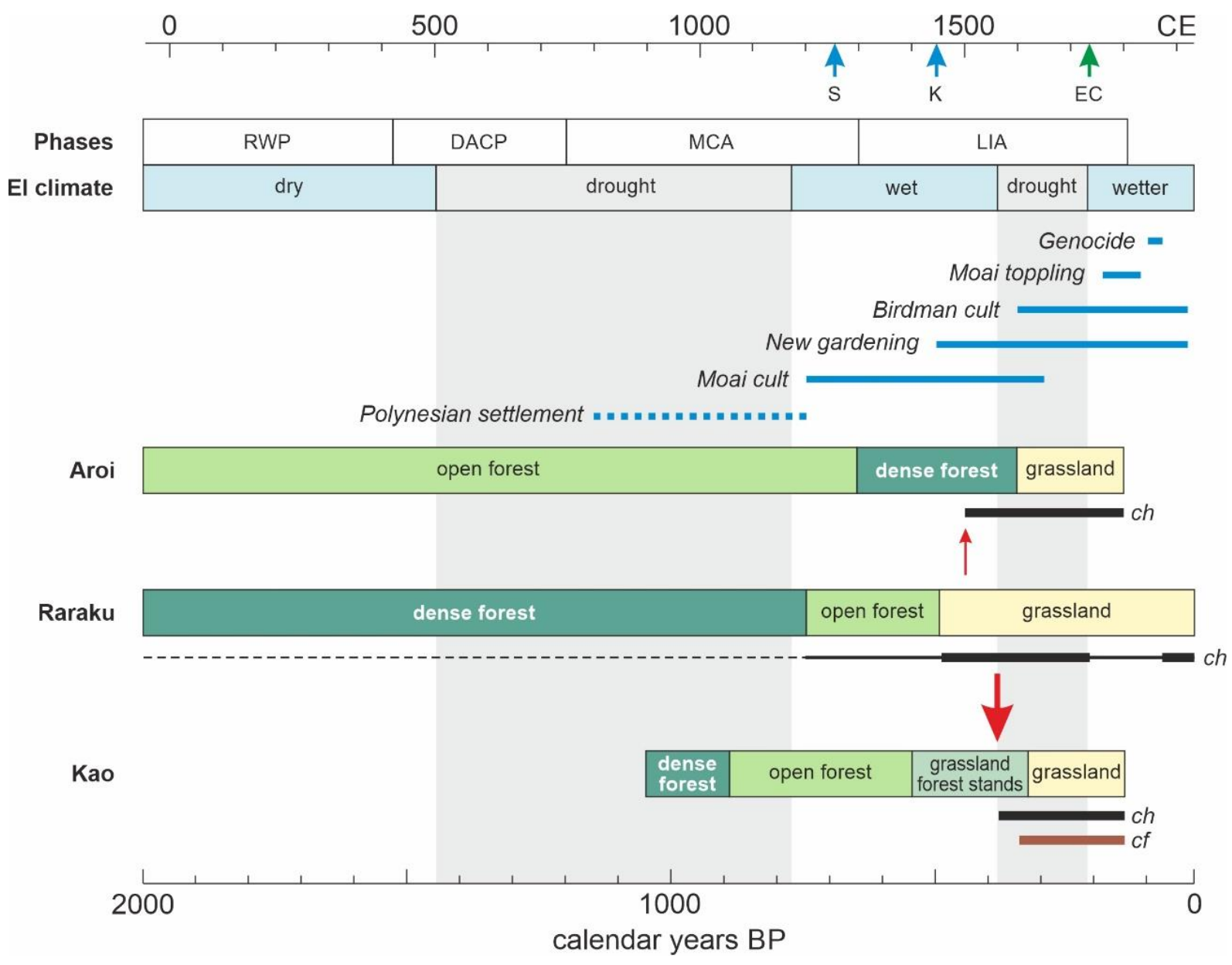

Figure 10 